\title{
ILMU SOSIAL DASAR
}

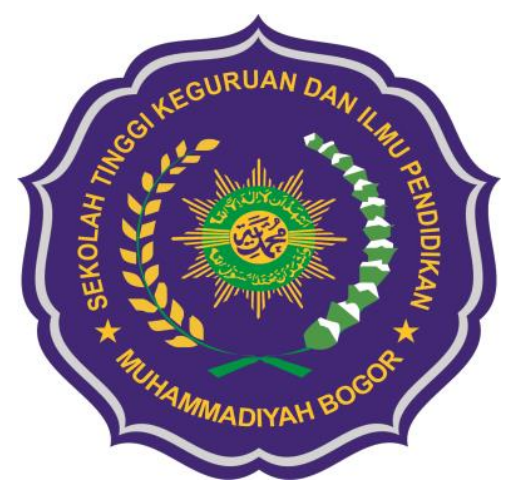

SULTONI

WAHYU BAGJA SULFEMI

STKIP MUHAMMADIYAH BOGOR 2007 


\section{KATA PENGANTAR}

Puji syukur penulis panjatkan kehadirat Allah SWT. Karena atas kehendakNyalah penyusunan laporan pembuatan Analisis Pembelajaran, Silabus, Rencana Pelaksanaan Pembelajaran (RPP), Kontrak Pembelajaran dan Rancangan tugas test uraian/objektif dapat terselesaikan

Laporan ini disampaikan di dalam pelatihan Applied Approach (AA) bagi dosen perguruan tinggi swasta dilingkungan kopertis wilayah IV. Pelatihan dilaksanakan di lingkungan kantor Kopertis di Jatinangor, Sumedang.

Dalam kesempatan ini pula, perkenankan penulis menghaturkan penghormatan dan ucapan terimakasih kepada :

1. Ketua STKIP Muhammadiyah Bogor yang telah memberikan kesempatan kepada penulis untuk mengikuti pelatihan ini;

2. Karyawan rumah tangga Kopertis Wilayah IV Jawa Barat dan Banten yang telah memberikan pelayanan yang sangat baik;

3. Teman-teman dosen peserta kegiatan AA yang selalu memberikan masukan, dorongan dan motivasi dalam penyusunan tugas mandiri ini.

Semoga hasil tugas mandiri ini dapat bermanfaat untuk keperluan pengembangan ilmu pengetahuan. Akhirnya kepada Allah jualah penulis mohon taufik hidayah, semoga usaha kami ini mendapat manfaat yang baik. Serta mendapat ridho dari Allah SWT. Amin ya rabbal alamin.

Penulis,

Wahyu Bagja Sulfemi, SS., M. 


\section{DAFTAR ISI}

Lembar Pengesahan ........................................................................ i

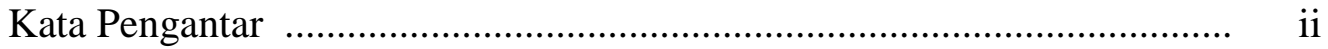

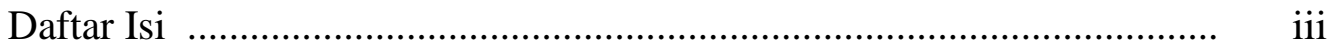

Analisis Pembelajaran ...................................................................... 1

Garis-garis Besar Program Pengajaran (GBPP) .................................... 2

Rencana Program Pengajaran (RPP) .................................................... 4

Kontrak Perkuliahan .................................................................... 18

Rancangan Tugas Pembelajaran ......................................................... 23

Kisi-kisi Tes Obyektif dan Test Uraian ................................................ 25 


\section{ANALISIS PEMBELAJARAN}

\section{Mata Kuliah Ilmu Sosial Dasar}

$\begin{array}{lll}\text { Judul Mata Kuliah } & : & \text { Ilmu Sosial Dasar } \\ \text { Nomor Kode MK } & : & \text { MKK } 100107 \\ \text { Jml SKS } & : & 2 \text { sks } \\ \text { DeskripsiSingkat } & : & \text { Mata kuliah Ilmu Sosial Dasar adalah salah satu dari } \\ & \text { mata kuliah kelompok Matakuliah Berkehidupan } \\ & \text { Bermasyarakat (MBB) di perguruan tinggi. Matakuliah } \\ & \text { ISD mengetengahkan pengetahuan dasar tentang } \\ & \text { konsep-konsep manusia, konsep-konsep kebudayaan, } \\ & \text { konsep-konsep sosiologi, konsep-konsep nilai, moral, } \\ & \text { dan hukum, dan konsep-konsep sains, teknoloi, seni, } \\ & \text { dan lingkungan } \\ & : \text { Setelah mengikuti matakuliah ini mahasiswa dapat } \\ & \text { menjelaskan konsep-konsep social dan budaya dasar } \\ \text { StandarKompetensi } & : \text { Wahyu Bagja Sulfemi, SS., }\end{array}$

\section{STANDAR KOMPETENSI}

Setelah mengikuti matakuliah ini, mahasiswa dapat menjelaskan konsep-konsep social dan budaya dasar

Menjelaskan makna lingkungan bagi keseiahteraan
Merumuskan manusia sebagai mahluk berbudaya, beretika, dan berestetika
Menjelaskan manusia dan peradaban, dan dinamika peradaban
Menjelaskan perlunya ISBD sebagai matakuliah MBB sebagai solos problem sosbud
Merumuskan hakikat, fungsi, nilai, moral, dan hukum dalam upaya mendapatkan keadilan, ketertiban dan kesejahteraan masyarakat
Mendefinisikan hakikat manusia sebagai individu dan mahluk sosial
Menyebutkan hakikat keragaman dan kesetaraan dalam dinamika sosial 


\section{SILABUS}

MATA KULIAH

KODE MATA KULIAH

KREDIT

SEMESTER

PENANGGUNG JAWAB MK

DESKRIPSI SINGKAT
: Ilmu Sosial Dasar

: MKK 100107

: 2 Sks

: 2 (dua)

: Wahyu Bagja Sulfemi, SS.

: Mata kuliah Ilmu Sosial Dasar adalah salah satu dari mata kuliah kelompok Matakuliah Berkehidupan Bermasyarakat (MBB) di perguruan tinggi. Matakuliah ISD mengetengahkan pengetahuan dasar tentang konsep-konsep manusia, konsep-konsep kebudayaan, konsep-konsep sosiologi, konsepkonsep nilai, moral, dan hukum, dan konsep-konsep sains, teknoloi, seni, dan lingkungan

STANDAR KOMPETENSI : Setelah mengikuti matakuliah ini mahasiswa dapat menjelaskan konsep-konsep social dan budaya dasar

\begin{tabular}{|c|c|c|c|c|c|c|c|}
\hline NO & $\begin{array}{c}\text { KOMPETEN } \\
\text { SI DASAR }\end{array}$ & $\begin{array}{c}\text { POKOK } \\
\text { BAHASAN } \\
\text { DALAM } \\
\text { MATA } \\
\text { KULIAH }\end{array}$ & $\begin{array}{c}\text { SUB POKOK } \\
\text { BAHASAN }\end{array}$ & METODE & MEDIA & WAKTU & PUSTAKA \\
\hline 1 & $\begin{array}{l}\text { SETELAH } \\
\text { MENGIKUTI } \\
\text { POKOK } \\
\text { BAHASAN } \\
\text { INI, } \\
\text { MAHASISWA } \\
: \\
\text { dapat } \\
\text { menjelaskan } \\
\text { perlunya ISD } \\
\text { sebagai } \\
\text { matakuliah } \\
\text { MBB sebagai } \\
\text { solusi problem } \\
\text { social budaya. }\end{array}$ & $\begin{array}{l}\text { hakikat dan } \\
\text { ruang } \\
\text { lingkup ISD }\end{array}$ & $\begin{array}{l}\text { 1. Hakikat } \\
\text { dan } \\
\text { ruang } \\
\text { lingkup } \\
\text { ISD, ISD } \\
\text { sebagai } \\
\text { MBB, } \\
\text { pendekata } \\
\text { n } \\
\text { interdisipli } \\
\text { ner dalam } \\
\text { ilmu sosial } \\
\text { budaya, } \\
\text { ISD } \\
\text { sebagai } \\
\text { Alternatif } \\
\text { pemecaha } \\
\text { n masalah } \\
\text { Sosial } \\
\text { budaya }\end{array}$ & $\begin{array}{l}\text { Ceramah, } \\
\text { diskusi dan } \\
\text { tanya } \\
\text { jawab }\end{array}$ & $\begin{array}{l}\text { OHP- } \\
\text { OHT, } \\
\text { LAPTO } \\
\text { P - } \\
\text { LCD }\end{array}$ & $\begin{array}{l}100 \\
\text { MENIT }\end{array}$ & $\begin{array}{l}\text { B W dan } \\
\text { BA }\end{array}$ \\
\hline
\end{tabular}




\begin{tabular}{|c|c|c|c|c|c|c|c|}
\hline & & & & & & & \\
\hline 2 & $\begin{array}{l}\text { Merumuskan } \\
\text { dan } \\
\text { mengespresika } \\
\text { n manusia } \\
\text { sebagai mahluk } \\
\text { berbudaya, } \\
\text { beretika, dan } \\
\text { berestetika }\end{array}$ & $\begin{array}{l}\text { manusia } \\
\text { sebagai } \\
\text { mahluk } \\
\text { berbudaya, } \\
\text { beretika, dan } \\
\text { berestetika }\end{array}$ & $\begin{array}{l}\text { 2. Hakikat } \\
\text { manusia } \\
\text { sebagai } \\
\text { mahluk } \\
\text { budaya } \\
\text { dan } \\
\text { Apresiasi } \\
\text { kemanusia } \\
\text { an dan } \\
\text { kebudayaa } \\
\text { n } \\
\text { 3. Etika dan } \\
\text { Estetika } \\
\text { budaya, } \\
\text { Konsep- } \\
\text { konsep } \\
\text { dasar } \\
\text { manusia } \\
\text { dan } \\
\text { memanusi } \\
\text { kan } \\
\text { manusia }\end{array}$ & $\begin{array}{l}\text { Ceramah, } \\
\text { diskusi dan } \\
\text { tanya } \\
\text { jawab }\end{array}$ & $\begin{array}{l}\text { OHP- } \\
\text { OHT, } \\
\text { LAPTO } \\
\text { P- } \\
\text { LCD }\end{array}$ & $\begin{array}{l}100 \\
\text { menit }\end{array}$ & $\begin{array}{l}\text { B W dan } \\
\text { BA }\end{array}$ \\
\hline 3 & $\begin{array}{l}\text { dapat } \\
\text { mendefinisikan } \\
\text { hakikat } \\
\text { manusia } \\
\text { sebagai } \\
\text { individu dan } \\
\text { mahluk sosial }\end{array}$ & $\begin{array}{l}\text { hakikat } \\
\text { manusia } \\
\text { sebagai } \\
\text { individu dan } \\
\text { mahluk sosial }\end{array}$ & $\begin{array}{ll}\text { 4. } & \text { Hakikat } \\
\text { manusia } \\
\text { sebagai } \\
\text { individu } \\
\text { dan } \\
\text { mahluk } \\
\text { sosial dan } \\
\text { Fungsi dan } \\
\text { peran } \\
\text { manusia } \\
\text { sebagai } \\
\text { individu } \\
\text { dan } \\
\text { mahluk } \\
\text { sosial } \\
\text { 5. Dinamika } \\
\text { interaksi } \\
\text { sosial dan } \\
\text { Dilema } \\
\text { kepentinga } \\
\text { n individu } \\
\text { dan } \\
\text { masyaraka } \\
\text { t }\end{array}$ & $\begin{array}{l}\text { Ceramah, } \\
\text { diskusi dan } \\
\text { tanya } \\
\text { jawab }\end{array}$ & $\begin{array}{l}\text { OHP- } \\
\text { OHT, } \\
\text { LAPTO } \\
\text { P- } \\
\text { LCD }\end{array}$ & $\begin{array}{l}100 \\
\text { menit }\end{array}$ & $\begin{array}{l}\text { B W dan } \\
\text { BA }\end{array}$ \\
\hline 4 & $\begin{array}{l}\text { dapat } \\
\text { menjelaskan } \\
\text { manusia dan } \\
\text { peradaban, dan } \\
\text { dinamika } \\
\end{array}$ & $\begin{array}{l}\text { hakikat } \\
\text { manusia dan } \\
\text { peradaban, } \\
\text { serta } \\
\text { dinamika }\end{array}$ & $\begin{array}{ll}\text { 6. } & \text { Hakikat } \\
\text { peradaban } \\
\text { Mahluk } \\
\text { beradab } \\
\text { dan } \\
\end{array}$ & $\begin{array}{l}\text { Ceramah, } \\
\text { diskusi dan } \\
\text { tanya } \\
\text { jawab }\end{array}$ & $\begin{array}{l}\text { OHP- } \\
\text { OHT, } \\
\text { LAPTO } \\
\text { P - } \\
\text { LCD }\end{array}$ & $\begin{array}{l}100 \\
\text { menit }\end{array}$ & $\begin{array}{l}\text { B W dan } \\
\text { BA }\end{array}$ \\
\hline
\end{tabular}




\begin{tabular}{|c|c|c|c|c|c|c|c|}
\hline & $\begin{array}{l}\text { peradaban } \\
\text { global }\end{array}$ & $\begin{array}{l}\text { peradaban } \\
\text { global }\end{array}$ & $\begin{array}{l}\text { masyaraka } \\
\text { t beradab } \\
\text { 7. } \\
\text { Evolusi } \\
\text { budaya } \\
\text { dan wujud } \\
\text { peradaban } \\
\text { Dinamika } \\
\text { peradaban } \\
\text { global } \\
\text { serta } \\
\text { Problemati } \\
\text { ka } \\
\text { peradaban }\end{array}$ & & & & \\
\hline & UTS & & 8. Materi1 -7 & & & & \\
\hline 5 & $\begin{array}{l}\text { dapat } \\
\text { menyebutkan } \\
\text { hakikat } \\
\text { keragaman dan } \\
\text { kesetaraan } \\
\text { dalam } \\
\text { dinamika sosial } \\
\text { manusia }\end{array}$ & $\begin{array}{l}\text { hakikat } \\
\text { keragaman } \\
\text { dan } \\
\text { kesetaraan } \\
\text { dalam } \\
\text { dinamika } \\
\text { sosial } \\
\text { manusia }\end{array}$ & $\begin{array}{l}\text { 9. Hakikat } \\
\text { keragaman } \\
\text { dan } \\
\text { kesetaraan } \\
\text { manusia } \\
\text { dan } \\
\text { Kemajemu } \\
\text { kan dalam } \\
\text { dinamika } \\
\text { sosial } \\
\text { budaya } \\
\text { 10. Keragama } \\
\text { n dan } \\
\text { kesetaraan } \\
\text { sebagai } \\
\text { kekayaan } \\
\text { sosial } \\
\text { budaya } \\
\text { Problemati } \\
\text { ka } \\
\text { keragaman } \\
\text { dan } \\
\text { kesetaraan }\end{array}$ & $\begin{array}{l}\text { Ceramah, } \\
\text { diskusi dan } \\
\text { tanya } \\
\text { jawab }\end{array}$ & $\begin{array}{l}\text { OHP- } \\
\text { OHT, } \\
\text { LAPTO } \\
\mathrm{P}_{-} \\
\text {LCD }^{-}\end{array}$ & $\begin{array}{l}100 \\
\text { menit }\end{array}$ & $\begin{array}{l}\text { B W dan } \\
\text { BA }\end{array}$ \\
\hline 6 & $\begin{array}{l}\text { dapat } \\
\text { merumuskan } \\
\text { hakikat, fungsi, } \\
\text { nilai, moral, } \\
\text { dan hukum } \\
\text { dalam upaya } \\
\text { mendapatkan } \\
\text { keadilan, } \\
\text { ketertiban dan } \\
\text { kesejahteraan } \\
\text { masyarakat }\end{array}$ & $\begin{array}{l}\text { hakikat, } \\
\text { fungsi, nilai, } \\
\text { moral, dan } \\
\text { hukum dalam } \\
\text { upaya } \\
\text { mendapatkan } \\
\text { keadilan, } \\
\text { ketertiban } \\
\text { dan } \\
\text { kesejahteraan } \\
\text { masyarakat }\end{array}$ & $\begin{array}{l}\text { 11. Mengkaji } \\
\text { hakikat, } \\
\text { fungsi, } \\
\text { nilai, } \\
\text { moral dan } \\
\text { hukum } \\
\text { dan } \\
\text { Mengkaji } \\
\text { keadilan, } \\
\text { ketertiban } \\
\text { dan } \\
\text { kesejahter } \\
\text { aan } \\
\text { 12. Mengident } \\
\text { ifikasi }\end{array}$ & $\begin{array}{l}\text { Ceramah, } \\
\text { diskusi dan } \\
\text { tanya } \\
\text { jawab }\end{array}$ & $\begin{array}{l}\text { OHP- } \\
\text { OHT, } \\
\text { LAPTO } \\
\mathrm{P}_{-} \\
\text {LCD }\end{array}$ & $\begin{array}{l}100 \\
\text { menit }\end{array}$ & $\begin{array}{l}\text { B W dan } \\
\text { BA }\end{array}$ \\
\hline
\end{tabular}




\begin{tabular}{|c|c|c|c|c|c|c|c|}
\hline & & & $\begin{array}{l}\text { perwujuda } \\
\mathrm{n} \\
\text { masyaraka } \\
\text { t bermoral } \\
\text { dan taat } \\
\text { hukum } \\
\text { serta } \\
\text { problemati } \\
\text { ka nilai, } \\
\text { moral, dan } \\
\text { hukum }\end{array}$ & & & & \\
\hline 7. & $\begin{array}{l}\text { dapat } \\
\text { menguraikan } \\
\text { hakikat dan } \\
\text { makna sains, } \\
\text { teknologi, dan } \\
\text { seni, dan } \\
\text { dampak dan } \\
\text { pemanfaatan } \\
\text { teknologi di } \\
\text { Indonesia }\end{array}$ & $\begin{array}{l}\text { hakikat dan } \\
\text { makna sains, } \\
\text { teknologi, } \\
\text { dan seni, dan } \\
\text { dampak dan } \\
\text { pemanfaatan } \\
\text { teknologi di } \\
\text { Indonesia }\end{array}$ & $\begin{array}{l}\text { 13. Hakikat } \\
\text { dan makna } \\
\text { sains, } \\
\text { teknologi, } \\
\text { dan seni } \\
\text { bagi } \\
\text { manusia } \\
\text { 14. Dampak } \\
\text { penyalahg } \\
\text { una-an } \\
\text { IPTEKS } \\
\text { pada } \\
\text { kehidupan } \\
\text { sosbud } \\
\text { serta } \\
\text { Problemati } \\
\text { ka } \\
\text { pemanfaat } \\
\text { an } \\
\text { IPTEKS di } \\
\text { Indone }\end{array}$ & $\begin{array}{l}\text { Ceramah, } \\
\text { diskusi dan } \\
\text { tanya } \\
\text { jawab }\end{array}$ & $\begin{array}{l}\text { OHP- } \\
\text { OHT, } \\
\text { LAPTO } \\
\text { P }-_{-} \\
\text {LCD }\end{array}$ & $\begin{array}{l}100 \\
\text { menit }\end{array}$ & $\begin{array}{l}\text { B W dan } \\
\text { BA }\end{array}$ \\
\hline 8. & $\begin{array}{l}\text { dapat } \\
\text { menguraian } \\
\text { hakikat dan } \\
\text { makna } \\
\text { lingkungan } \\
\text { bagi } \\
\text { kesejahteraan }\end{array}$ & $\begin{array}{l}\text { hakikat dan } \\
\text { makna } \\
\text { lingkungan } \\
\text { bagi } \\
\text { kesejahteraan }\end{array}$ & $\begin{array}{l}\text { 15. Hakikat } \\
\text { dan makna } \\
\text { lingkunga } \\
\text { n bagi } \\
\text { manusia } \\
\text { dan } \\
\text { Kualitas } \\
\text { penduduk } \\
\text { dan } \\
\text { lingkunga } \\
\text { n terhadap } \\
\text { kesejahter } \\
\text { aan } \\
\text { 16. Problema } \\
\text { lingkunga } \\
\text { n sosial } \\
\text { budaya } \\
\text { dan Isu-isu } \\
\text { penting } \\
\text { tentang }\end{array}$ & $\begin{array}{l}\text { Ceramah, } \\
\text { diskusi dan } \\
\text { tanya } \\
\text { jawab }\end{array}$ & $\begin{array}{l}\text { OHP- } \\
\text { OHT, } \\
\text { LAPTO } \\
\text { P }-_{-} \\
\text {LCD }\end{array}$ & $\begin{array}{l}100 \\
\text { menit }\end{array}$ & $\begin{array}{l}\text { B W dan } \\
\text { BA }\end{array}$ \\
\hline
\end{tabular}




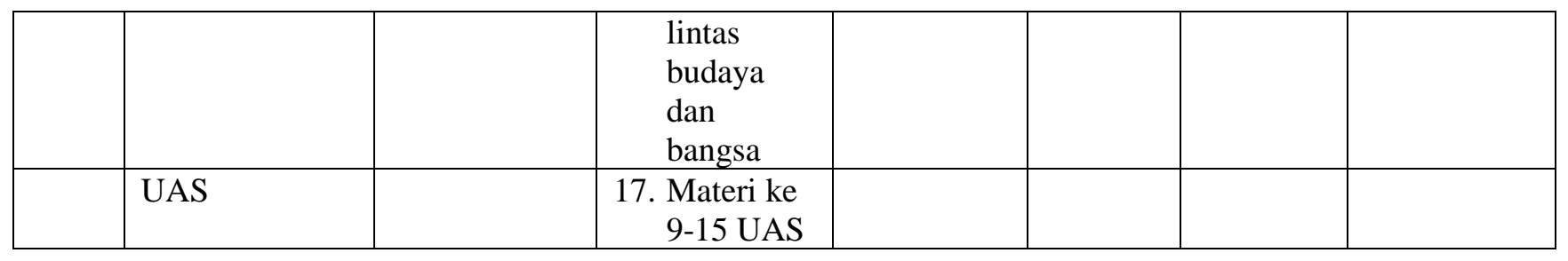




\section{RENCANA PROGRAM PEMBELAJARAN}

(RPP)

$\begin{array}{ll}\text { Mata kuliah } & : \text { Ilmu Sosial Dasar } \\ \text { Kode Matakuliah } & : \text { MKK } 100107 \\ \text { sks } & : 2 \\ \text { Waktu pertemuan } & : 2 \text { X 50 menit }\end{array}$

A. Tujuan

1. Standar Kompetensi

mahasiswa dapat menjelaskan konsep-konsep social : dan budaya dasar

2. Kompetensi Dasar

: Menjelaskan perlunya ISD sebagai matakuliah MBB sebagai solosi problem social budaya

B. Pokok Bahasan : Hakikat dan ruang lingkup ISD

C. Sub Pokok Bahasan $\quad$ : Hakikat dan ruang lingkup ISD

Pentingnya pendekatan interdisipliner dalam ilmu sosial budaya

ISD sebagai solosi problem social budaya

D. Kegiatan Belajar Mengajar : Pertemuan ke 1 (satu)

\begin{tabular}{|c|c|c|c|c|}
\hline $\begin{array}{c}\text { TAHAP } \\
\text { KEGIATAN }\end{array}$ & $\begin{array}{l}\text { KEGIATAN } \\
\text { DOSEN }\end{array}$ & $\begin{array}{l}\text { KEGIATAN } \\
\text { MAHASISWA }\end{array}$ & WAKTU & $\begin{array}{c}\text { MEDIA DAN } \\
\text { ALAT } \\
\text { PENGAJARAN }\end{array}$ \\
\hline Pendahuluan & $\begin{array}{l}\text { 1. Mengucapkan } \\
\text { salam dan } \\
\text { menjelaskan } \\
\text { cakupan } \\
\text { materi } \\
\text { pertemuan } \\
\text { ke-1; } \\
\text { 2. Menjelaskan } \\
\text { manfaat } \\
\text { materi } \\
\text { pertemuan } \\
\text { ke-1; } \\
\text { 3. Relevansi } \\
\text { antara }\end{array}$ & $\begin{array}{l}\text { Memperhatikan } \\
\text { dan diskusi. }\end{array}$ & 10 Menit & $\begin{array}{l}\text { Laptop, } \\
\text { LCD/Infocus dan } \\
\text { White board. }\end{array}$ \\
\hline
\end{tabular}




\begin{tabular}{|l|l|l|l|l|}
\hline & $\begin{array}{l}\text { standart } \\
\text { kompetensi } \\
\text { dengan } \\
\text { kompetensi } \\
\text { dasar. }\end{array}$ & & & \\
\hline Penyajian & $\begin{array}{l}\text { 4. Menjelaskan. } \\
\text { Hakikat dan } \\
\text { ruang } \\
\text { lingkup ISD }\end{array}$ & $\begin{array}{l}\text { Memperhatikan } \\
\text { dan diskusi. }\end{array}$ & 80 Menit & $\begin{array}{l}\text { Laptop, } \\
\text { LCD/Infocus dan } \\
\text { White board. }\end{array}$ \\
\hline Penutup & $\begin{array}{l}\text { 5. Menunjuk } \\
\text { beberapa } \\
\text { mahasiswa } \\
\text { secara acak } \\
\text { untuk } \\
\text { menjawab } \\
\text { pertanyaan. }\end{array}$ & $\begin{array}{l}\text { Menjawab } \\
\text { pertanyaan. }\end{array}$ & 10 Menit & \\
& & & \\
\hline
\end{tabular}

E. EVALUASI $\quad:$ 1. Jelaskan pengertian, tujuan \& fungsi ilmu sosial budaya dasar?

2. Jelaskan pendekatan interdisipliner dalam ilmu sosial budaya 


\section{RENNCANA PROGRAM PEMBELAJARAN}

(RPP)

$\begin{array}{ll}\text { Mata kuliah } & : \text { Ilmu Sosial Dasar } \\ \text { Kode Matakuliah } & : \text { MKK } 100107 \\ \text { sks } & : 2 \\ \text { Waktu pertemuan } & : 2 \times 50 \text { menit }\end{array}$

A. Tujuan

1. Standar Kompetensi Mahasiswa dapat menjelaskan konsep-konsep social : dan budaya

2. Kompetensi Dasar

B. Pokok Bahasan

C. Sub Pokok Bahasan
: Merumuskan manusia sebagai mahluk berbudaya, beretika, dan berestetika

: Manusia sebagai mahluk berbudaya, beretika, dan berestetika

: 1. Hakikat Manusia sebagai mahluk budaya.

2. Apresiasi terhadap kemanusiaan.

D. Kegiatan Belajar Mengajar : Pertemuan ke 2 (dua)

\begin{tabular}{|c|c|c|c|c|}
\hline $\begin{array}{c}\text { TAHAP } \\
\text { KEGIATAN }\end{array}$ & $\begin{array}{l}\text { KEGIATAN } \\
\text { DOSEN }\end{array}$ & $\begin{array}{l}\text { KEGIATAN } \\
\text { MAHASISWA }\end{array}$ & WAKTU & $\begin{array}{c}\text { MEDIA DAN } \\
\text { ALAT } \\
\text { PENGAJARAN }\end{array}$ \\
\hline Pendahuluan & $\begin{array}{l}\text { 1. Mengucapkan } \\
\text { salam dan } \\
\text { menjelaskan } \\
\text { cakupan materi } \\
\text { pertemuan ke- } \\
2 \text {; } \\
\text { 2. Menjelaskan } \\
\text { manfaat materi } \\
\text { pertemuan ke- } \\
\text { 2; } \\
\text { 3. Relevansi } \\
\text { antara standart } \\
\text { kompetensi } \\
\text { dengan } \\
\text { kompetensi } \\
\text { dasar. }\end{array}$ & $\begin{array}{l}\text { Memperhatikan } \\
\text { dan diskusi. }\end{array}$ & 10 Menit & $\begin{array}{l}\text { Laptop, } \\
\text { LCD/Infocus dan } \\
\text { White board. }\end{array}$ \\
\hline Penyajian & 1. Menjelaskan & Memperhatikan & 75 Menit & Laptop, \\
\hline
\end{tabular}




\begin{tabular}{|l|l|l|l|l|}
\hline & $\begin{array}{l}\text { Hakikat } \\
\text { manusia } \\
\text { sebagai mahluk } \\
\text { budaya dan } \\
\text { Apresiasi } \\
\text { kemanusiaan } \\
\text { terhadap } \\
\text { kebudayaan }\end{array}$ & dan diskusi. & & $\begin{array}{l}\text { LCD/Infocus dan } \\
\text { White board. }\end{array}$ \\
\hline Penutup & $\begin{array}{l}\text { 2. Menunjuk } \\
\text { beberapa } \\
\text { mahasiswa } \\
\text { secara acak } \\
\text { untuk } \\
\text { menjawab } \\
\text { pertanyaan. }\end{array}$ & $\begin{array}{l}\text { Menjawab } \\
\text { pertanyaan, } \\
\text { memberikan } \\
\text { pendapat dan } \\
\text { memperhatikan }\end{array}$ & 15 Menit & \\
& & & \\
\hline
\end{tabular}

E. EVALUASI : 1. Jelaskan yang dimaksud dengan hakikat manusia sebagai mahluk budaya

2. Jelaskan Apresiasi manusia terhadap kebudayaan 


\section{RENCANA PROGRAM PEMBELAJARAN}

(RPP)
Mata kuliah
: Ilmu Sosial
Dasar
Kode Matakuliah
: MKK 100107
sks
$: 2$
Waktu pertemuan
: $2 \times 50$ menit

\section{A. Tujuan}

1. Standar Kompetensi

Mahasiswa dapat menjelaskan konsep-konsep social : dan budaya dasar

2. Kompetensi Dasar

: Merumuskan manusia sebagai mahluk berbudaya, beretika, dan berestetika

B. Pokok Bahasan

: manusia sebagai mahluk berbudaya, beretika, dan berestetika

C. Sub Pokok Bahasan : Etika dan Estetika budaya, Konsep-konsep dasar manusia dan memanusikan manusia

D. Kegiatan Belajar Mengajar : Pertemuan ke 3 (tiga)

\begin{tabular}{|c|c|c|c|c|}
\hline $\begin{array}{c}\text { TAHAP } \\
\text { KEGIATAN }\end{array}$ & $\begin{array}{l}\text { KEGIATAN } \\
\text { DOSEN }\end{array}$ & $\begin{array}{c}\text { KEGIATAN } \\
\text { MAHASISWA }\end{array}$ & WAKTU & $\begin{array}{c}\text { MEDIA DAN } \\
\text { ALAT } \\
\text { PENGAJARAN }\end{array}$ \\
\hline Pendahuluan & $\begin{array}{l}\text { 1. Mengucapkan } \\
\text { salam dan } \\
\text { menjelaskan } \\
\text { cakupan materi } \\
\text { pertemuan ke- } \\
\text { 3; } \\
\text { 2. Menjelaskan } \\
\text { manfaat materi } \\
\text { pertemuan ke- } \\
\text { 3; } \\
\text { 3. Relevansi } \\
\text { antara standart } \\
\text { kompetensi } \\
\text { dengan } \\
\text { kompetensi } \\
\text { dasar. }\end{array}$ & $\begin{array}{l}\text { Memperhatikan } \\
\text { dan diskusi. }\end{array}$ & 10 Menit & $\begin{array}{l}\text { Laptop, } \\
\text { LCD/Infocus dan } \\
\text { White board. }\end{array}$ \\
\hline Penyajian & $\begin{array}{l}\text { 4. Menjelaskan } \\
\text { etika dan }\end{array}$ & Memperhatikan & 75 Menit & $\begin{array}{l}\text { Laptop, } \\
\text { LCD/Infocus dan }\end{array}$ \\
\hline
\end{tabular}




\begin{tabular}{|l|l|l|l|l|}
\hline & $\begin{array}{l}\text { estetika budaya } \\
\text { dan Konsep- } \\
\text { konsep dasar } \\
\text { manusia dan } \\
\text { Problema } \\
\text { kebudayaan }\end{array}$ & dan diskusi. & & White board. \\
\hline Penutup & $\begin{array}{l}\text { 5. Menunjuk } \\
\text { beberapa } \\
\text { mahasiswa } \\
\text { secara acak } \\
\text { untuk } \\
\text { menjawab } \\
\text { pertanyaan. }\end{array}$ & $\begin{array}{l}\text { Menjawab } \\
\text { pertanyaan, } \\
\text { memberikan } \\
\text { mendapat dan } \\
\text { memperhatikan }\end{array}$ & 15 Menit & \\
\end{tabular}

E. EVALUASI : 1. konsep dasar manusia dalam memanusikan manusia 2. Jelaskan Etika dan Estetika dalam budaya 


\section{RENCANA PROGRAM PEMBELAJARAN}

(RPP)

$\begin{array}{ll}\text { Mata kuliah } & : \text { Ilmu Sosial Dasar } \\ \text { Kode Matakuliah } & : \text { MKK } 100107 \\ \text { sks } & : 2 \\ \text { Waktu pertemuan } & : 2 \times 50 \text { menit }\end{array}$

A. Tujuan

1. Standar Kompetensi Mahasiswa dapat menjelaskan konsep-konsep social : dan budaya dasar

2. Kompetensi Dasar

B. Pokok Bahasan

C. Sub Pokok Bahasan
: Mendefinisikan hakikat manusia sebagai individu dan mahluk sosial

: hakikat manusia sebagai individu dan mahluk sosial

: Hakikat manusia sebagai individu dan mahluk sosial. Fungsi dan peran manusia sebagai individu dan mahluk sosial

D. Kegiatan Belajar Mengajar : Pertemuan ke 4 (Empat)

\begin{tabular}{|c|c|c|c|c|}
\hline $\begin{array}{c}\text { TAHAP } \\
\text { KEGIATAN }\end{array}$ & $\begin{array}{l}\text { KEGIATAN } \\
\text { DOSEN }\end{array}$ & $\begin{array}{c}\text { KEGIATAN } \\
\text { MAHASISWA }\end{array}$ & WAKTU & $\begin{array}{c}\text { MEDIA DAN } \\
\text { ALAT } \\
\text { PENGAJARAN }\end{array}$ \\
\hline Pendahuluan & $\begin{array}{l}\text { 1. Mengucapk } \\
\text { an salam } \\
\text { dan } \\
\text { menjelaska } \\
\text { n cakupan } \\
\text { materi } \\
\text { pertemuan } \\
\text { ke-4; } \\
\text { 2. Menjelaska } \\
\text { n manfaat } \\
\text { materi } \\
\text { pertemuan } \\
\text { ke-4; } \\
\text { 3. Relevansi } \\
\text { antara } \\
\text { standart } \\
\text { kompetensi } \\
\text { dengan } \\
\text { kompetensi }\end{array}$ & $\begin{array}{l}\text { Memperhatikan } \\
\text { dan diskusi. }\end{array}$ & 10 Menit & $\begin{array}{l}\text { Laptop, } \\
\text { LCD/Infocus dan } \\
\text { White board. }\end{array}$ \\
\hline
\end{tabular}




\begin{tabular}{|c|c|c|c|c|}
\hline & dasar. & & & \\
\hline Penyajian & $\begin{array}{l}\text { 1. Menjelaska } \\
\text { n Hakikat } \\
\text { manusia } \\
\text { sebagai } \\
\text { individu } \\
\text { dan mahluk } \\
\text { sosial dan } \\
\text { Fungsi dan } \\
\text { peran } \\
\text { manusia } \\
\text { sebagai } \\
\text { individu } \\
\text { dan mahluk } \\
\text { sosial }\end{array}$ & $\begin{array}{l}\text { Memperhatikan } \\
\text { dan diskusi. }\end{array}$ & 75 Menit & $\begin{array}{l}\text { Laptop, } \\
\text { LCD/Infocus dan } \\
\text { White board. }\end{array}$ \\
\hline Penutup & $\begin{array}{l}\text { 2. Menunjuk } \\
\text { beberapa } \\
\text { mahasiswa } \\
\text { secara acak } \\
\text { untuk } \\
\text { menjawab } \\
\text { pertanyaan. }\end{array}$ & $\begin{array}{l}\text { Menjawab } \\
\text { pertanyaaan, } \\
\text { memberikan } \\
\text { pendapat dan } \\
\text { memperhatikan }\end{array}$ & 15 Menit & \\
\hline
\end{tabular}

E. EVALUASI

F. REFERENSI
: 1. Jelaskan Hakikat manusia sebagai individu dan mahluk sosial

2. Jelaskan Fungsi dan peran manusia sebagai individu dan mahluk sosial

1. Schuon, F. 1997. Hakikat Manusia. Pustaka Pelajar. Yogakarta.

2. Soekanto, Soejono. 1983. Struktur Masyarakat. Rajawali. Jakart

3. Setiadi, Elly M. dkk. 2006. ISD. Kencana. Jakarta.

4. Suleman, munandar. 1995. Ilmu Budaya Dasar. Eresco. Bandung. 


\section{RENCANA PROGRAM PEMBELAJARAN}

(RPP)

$\begin{array}{ll}\text { Mata kuliah } & : \text { Ilmu Sosial Dasar } \\ \text { Kode Matakuliah } & : \text { MKK } 100107 \\ \text { sks } & : 2 \\ \text { Waktu pertemuan } & : 2 \times 50 \text { menit }\end{array}$

\section{A. Tujuan}

1. Standar Kompetensi

Mahasiswa dapat menjelaskan konsep-konsep social

: dan budaya dasar

2. Kompetensi Dasar

: Mendefinisikan hakikat manusia sebagai individu dan mahluk sosial

B. Pokok Bahasan

: hakikat manusia sebagai individu dan mahluk sosial

C. Sub Pokok Bahasan

: Dinamika interaksi sosial dan Dilema kepentingan individu dan masyarakat

D. Kegiatan Belajar Mengajar : Pertemuan ke 5 (lima)

\begin{tabular}{|c|c|c|c|c|}
\hline $\begin{array}{c}\text { TAHAP } \\
\text { KEGIATAN }\end{array}$ & $\begin{array}{l}\text { KEGIATAN } \\
\text { DOSEN }\end{array}$ & $\begin{array}{l}\text { KEGIATAN } \\
\text { MAHASISWA }\end{array}$ & WAKTU & $\begin{array}{c}\text { MEDIA DAN } \\
\text { ALAT } \\
\text { PENGAJARAN }\end{array}$ \\
\hline Pendahuluan & $\begin{array}{l}\text { 1. Mengucapkan } \\
\text { salam dan } \\
\text { menjelaskan } \\
\text { cakupan } \\
\text { materi } \\
\text { pertemuan ke- } \\
5 ; \\
\text { 2. Menjelaskan } \\
\text { manfaat } \\
\text { materi } \\
\text { pertemuan ke- } \\
\text { 5; } \\
\text { 3. Relevansi } \\
\text { antara standart } \\
\text { kompetensi }\end{array}$ & $\begin{array}{l}\text { Memperhatikan } \\
\text { dan diskusi. }\end{array}$ & 10 Menit & $\begin{array}{l}\text { Laptop, } \\
\text { LCD/Infocus dan } \\
\text { White board. }\end{array}$ \\
\hline
\end{tabular}




\begin{tabular}{|l|l|l|l|l|}
\hline & $\begin{array}{l}\text { dengan } \\
\text { kompetensi } \\
\text { dasar. }\end{array}$ & & \\
\hline Penyajian & $\begin{array}{l}\text { Menjelaskan } \\
\text { Dinamika } \\
\text { interaksi } \\
\text { sosial dan } \\
\text { Dilema } \\
\text { kepentingan } \\
\text { individu dan } \\
\text { masyarakat }\end{array}$ & $\begin{array}{l}\text { Memperhatikan } \\
\text { dan diskusi. }\end{array}$ & 75 Menit & $\begin{array}{l}\text { Laptop, } \\
\text { LCD/Infocus dan } \\
\text { White board. }\end{array}$ \\
\hline Penutup & $\begin{array}{l}\text { Menuk } \\
\text { beberapa } \\
\text { mahasiswa } \\
\text { secara acak } \\
\text { untuk } \\
\text { menjawab } \\
\text { pertanyaan. }\end{array}$ & $\begin{array}{l}\text { Menjawab } \\
\text { pertanyaan, } \\
\text { memberikan } \\
\text { pendapat dan } \\
\text { memperhatikan }\end{array}$ & 15 Menit & \\
\hline
\end{tabular}

E. EVALUASI : jelaskan dinamika interaksi sosial dan dilema kepentingan individu dan masyarakat 


\section{RENCANA PROGRAM PEMBELAJARAN}

$(\mathbf{R P P})$

$\begin{array}{ll}\text { Mata kuliah } & \text { : Ilmu Sosial Dasar } \\ \text { Kode Matakuliah } & : \text { MKK } 100107 \\ \text { sks } & : 2 \\ \text { Waktu pertemuan } & : 2 \times 50 \text { menit }\end{array}$

A. Tujuan

1. Standar Kompetensi Mahasiswa dapat menjelaskan konsep-konsep social : dan budaya dasar

2. Kompetensi Dasar

: Menjelaskan hakikat manusia dan peradaban, serta dinamika peradaban global

B. Pokok Bahasan

: hakikat manusia dan peradaban, serta dinamika peradaban global

C. Sub Pokok Bahasan : Hakikat peradaban Mahluk beradab dan masyarakat beradab

D. Kegiatan Belajar Mengajar : Pertemuan ke 6 (Empat)

\begin{tabular}{|l|l|l|l|l|}
\hline $\begin{array}{c}\text { TAHAP } \\
\text { KEGIATAN }\end{array}$ & $\begin{array}{c}\text { KEGIATAN } \\
\text { DOSEN }\end{array}$ & $\begin{array}{c}\text { KEGIATAN } \\
\text { MAHASISWA }\end{array}$ & WAKTU & $\begin{array}{c}\text { MEDIA DAN } \\
\text { ALAT } \\
\text { PENGAJARAN }\end{array}$ \\
\hline Pendahuluan & $\begin{array}{c}\text { 1. Mengucapka } \\
\text { n salam dan } \\
\text { menjelaskan } \\
\text { cakupan } \\
\text { materi } \\
\text { pertemuan } \\
\text { ke-6; }\end{array}$ & $\begin{array}{l}\text { Memperhatikan } \\
\text { dan diskusi. }\end{array}$ & 10 Menit & $\begin{array}{l}\text { Laptop, } \\
\text { LCD/Infocus dan } \\
\text { White board. }\end{array}$ \\
& 2. Menjelaskan \\
& manfaat & & \\
materi & & & \\
pertemuan & & & \\
ke-6; & & & \\
& & & \\
\hline
\end{tabular}




\begin{tabular}{|l|l|l|l|l|}
\hline & $\begin{array}{l}\text { antara } \\
\text { standart } \\
\text { kompetensi } \\
\text { dengan } \\
\text { kompetensi } \\
\text { dasar. }\end{array}$ & & & \\
\hline Penyajian & $\begin{array}{l}\text { menjelaskan } \\
\text { Hakikat } \\
\text { peradaban , } \\
\text { mahluk beradab } \\
\text { dan masyarakat } \\
\text { beradab }\end{array}$ & $\begin{array}{l}\text { Memperhatikan } \\
\text { dan diskusi. }\end{array}$ & 75 Menit & $\begin{array}{l}\text { Laptop, } \\
\text { LCD/Infocus dan } \\
\text { White board. }\end{array}$ \\
\hline Penutup & $\begin{array}{l}\text { Menunjuk } \\
\text { beberapa } \\
\text { mahasiswa } \\
\text { secara acak } \\
\text { untuk } \\
\text { menjawab } \\
\text { pertanyaan. }\end{array}$ & $\begin{array}{l}\text { Menjawab } \\
\text { pertanyaan, } \\
\text { memberikan } \\
\text { pendapat dan } \\
\text { memperhatikan }\end{array}$ & 15 Menit & \\
& & & \\
& & & \\
& & & \\
\hline
\end{tabular}

E. EVALUASI : jelaskan hakikat peradaban masyarakat beradab? 


\section{RENCANA PROGRAM PEMBELAJARAN}

(RPP)

$\begin{array}{ll}\text { Mata kuliah } & : \text { Ilmu Sosial Dasar } \\ \text { Kode Matakuliah } & : \text { MKK } 100107 \\ \text { sks } & : 2 \\ \text { Waktu pertemuan } & : 2 \times 50 \text { menit }\end{array}$

A. Tujuan

1. Standar Kompetensi

Mahasiswa dapat menjelaskan konsep-konsep social

: dan budaya dasar

2. Kompetensi Dasar

: Menjelaskan hakikat manusia dan peradaban, serta dinamika peradaban global

B. Pokok Bahasan

: hakikat manusia dan peradaban, serta dinamika peradaban global

C. Sub Pokok Bahasan $\quad$ : Evolusi budaya dan wujud peradaban Dinamika peradaban global serta Problematika peradaban

D. Kegiatan Belajar Mengajar : Pertemuan ke 7 (Tujuh)

\begin{tabular}{|c|c|c|c|c|}
\hline $\begin{array}{c}\text { TAHAP } \\
\text { KEGIATAN }\end{array}$ & $\begin{array}{c}\text { KEGIATAN } \\
\text { DOSEN }\end{array}$ & $\begin{array}{l}\text { KEGIATAN } \\
\text { MAHASISWA }\end{array}$ & WAKTU & $\begin{array}{c}\text { MEDIA DAN } \\
\text { ALAT } \\
\text { PENGAJARAN }\end{array}$ \\
\hline Pendahuluan & $\begin{array}{l}\text { 1. Mengucapka } \\
\text { n salam dan } \\
\text { menjelaskan } \\
\text { cakupan } \\
\text { materi } \\
\text { pertemuan } \\
\text { ke-7; } \\
\text { 2. Menjelaskan } \\
\text { manfaat } \\
\text { materi } \\
\text { pertemuan } \\
\text { ke-7; } \\
\text { 3. Relevansi } \\
\text { antara } \\
\text { standart } \\
\text { kompetensi }\end{array}$ & $\begin{array}{l}\text { Memperhatikan } \\
\text { dan diskusi. }\end{array}$ & 10 Menit & $\begin{array}{l}\text { Laptop, } \\
\text { LCD/Infocus dan } \\
\text { White board. }\end{array}$ \\
\hline
\end{tabular}




\begin{tabular}{|l|l|l|l|l|}
\hline & $\begin{array}{l}\text { dengan } \\
\text { kompetensi } \\
\text { dasar. }\end{array}$ & & \\
\hline Penyajian & $\begin{array}{l}\text { Menjelaskan } \\
\text { evolusi budaya } \\
\text { dan wujud } \\
\text { peradaban } \\
\text { serta diinamika } \\
\text { peradaban } \\
\text { global serta } \\
\text { Problematika } \\
\text { peradaban }\end{array}$ & $\begin{array}{l}\text { Memperhatikan } \\
\text { dan diskusi. }\end{array}$ & 75 Menit & $\begin{array}{l}\text { Laptop, } \\
\text { LCD/Infocus dan } \\
\text { White board. }\end{array}$ \\
\hline Penutup & $\begin{array}{l}\text { Menunjuk } \\
\text { beberapa } \\
\text { mahasiswa } \\
\text { secara acak } \\
\text { untuk } \\
\text { menjawab } \\
\text { pertanyaan. }\end{array}$ & $\begin{array}{l}\text { Menjawab } \\
\text { pertanyaan, } \\
\text { memberikan } \\
\text { pendapat dan } \\
\text { memperhatikan }\end{array}$ & & \\
& & & \\
& & & \\
\hline
\end{tabular}

E. EVALUASI : Jelaskan evolusi budaya dan wujud peradaban serta diinamika peradaban global serta Problematika peradaban 


\section{RENCANA PROGRAM PEMBELAJARAN}

$(\mathbf{R P P})$

$\begin{array}{ll}\text { Mata kuliah } & : \text { Ilmu Sosial Dasar } \\ \text { Kode Matakuliah } & : \text { MKK } 100107 \\ \text { sks } & : 2 \\ \text { Waktu pertemuan } & : 2 \times 50 \text { menit }\end{array}$

A. Tujuan

1. Standar Kompetensi

Mahasiswa dapat menjelaskan konsep-konsep social : dan budaya dasar

2. Kompetensi Dasar

: Menyebutkan hakikat keragaman dan kesetaraan dalam dinamika sosial manusia

B. Pokok Bahasan

: hakikat keragaman dan kesetaraan dalam dinamika sosial manusia

C. Sub Pokok Bahasan : Hakikat keragaman dan kesetaraanmanusia dan Kemajemukan dalam dinamika sosial budaya

D. Kegiatan Belajar Mengajar : Pertemuan ke 9 (sembilan)

\begin{tabular}{|c|c|c|c|c|}
\hline $\begin{array}{c}\text { TAHAP } \\
\text { KEGIATAN }\end{array}$ & $\begin{array}{l}\text { KEGIATAN } \\
\text { DOSEN }\end{array}$ & $\begin{array}{c}\text { KEGIATAN } \\
\text { MAHASISWA }\end{array}$ & WAKTU & $\begin{array}{c}\text { MEDIA DAN } \\
\text { ALAT } \\
\text { PENGAJARAN }\end{array}$ \\
\hline Pendahuluan & $\begin{array}{l}\text { 1. Mengucapkan } \\
\text { salam dan } \\
\text { menjelaskan } \\
\text { cakupan } \\
\text { materi } \\
\text { pertemuan ke- } \\
8 \text {; } \\
\text { 2. Menjelaskan } \\
\text { manfaat } \\
\text { materi } \\
\text { pertemuan ke- } \\
\text { 8; } \\
\text { 3. Relevansi } \\
\text { antara standart } \\
\text { kompetensi } \\
\text { dengan } \\
\text { kompetensi }\end{array}$ & $\begin{array}{l}\text { Memperhatikan } \\
\text { dan diskusi. }\end{array}$ & 10 Menit & $\begin{array}{l}\text { Laptop, } \\
\text { LCD/Infocus dan } \\
\text { White board. }\end{array}$ \\
\hline
\end{tabular}




\begin{tabular}{|c|c|c|c|c|}
\hline & dasar. & & & \\
\hline Penyajian & $\begin{array}{l}\text { 4. Menjelaskan } \\
\text { Hakikat } \\
\text { keragaman } \\
\text { dan } \\
\text { kesetaraanma } \\
\text { nusia dan } \\
\text { Kemajemukan } \\
\text { dalam } \\
\text { dinamika } \\
\text { sosial budaya }\end{array}$ & $\begin{array}{l}\text { Memperhatikan } \\
\text { dan diskusi. }\end{array}$ & 75 Menit & $\begin{array}{l}\text { Laptop, } \\
\text { LCD/Infocus dan } \\
\text { White board. }\end{array}$ \\
\hline Penutup & $\begin{array}{l}\text { 5. Menunjuk } \\
\text { beberapa } \\
\text { mahasiswa } \\
\text { secara acak } \\
\text { untuk } \\
\text { menjawab } \\
\text { pertanyaan. }\end{array}$ & $\begin{array}{l}\text { Menjawab } \\
\text { pertanyaan, } \\
\text { memberikan } \\
\text { pendapat dan } \\
\text { memperhatikan }\end{array}$ & 15 Menit & \\
\hline
\end{tabular}

E. EVALUASI : 1. Jelaskan Hakikat keragaman dan kesetaraan manusia?

2. Jelaskan kemajemukan dalam dinamika sosial budaya? 


\section{RENCANA PROGRAM PEMBELAJARAN}

$(\mathbf{R P P})$

$\begin{array}{ll}\text { Mata kuliah } & : \text { Ilmu Sosial Dasar } \\ \text { Kode Matakuliah } & : \text { MKK } 100107 \\ \text { sks } & : 2 \\ \text { Waktu pertemuan } & : 2 \times 50 \text { menit }\end{array}$

A. Tujuan

1. Standar Kompetensi

Mahasiswa dapat menjelaskan konsep-konsep social : dan budaya dasar

2. Kompetensi Dasar

: Menyebutkan hakikat keragaman dan kesetaraan dalam dinamika sosial manusia

B. Pokok Bahasan

: hakikat keragaman dan kesetaraan dalam dinamika sosial manusia

C. Sub Pokok Bahasan $\quad$ : Keragaman dan kesetaraan sebagai kekayaan sosial budaya Problematika keragaman dan kesetaraan

D. Kegiatan Belajar Mengajar : Pertemuan ke 10 (sepuluh)

\begin{tabular}{|c|c|c|c|c|}
\hline $\begin{array}{c}\text { TAHAP } \\
\text { KEGIATAN }\end{array}$ & $\begin{array}{l}\text { KEGIATAN } \\
\text { DOSEN }\end{array}$ & $\begin{array}{c}\text { KEGIATAN } \\
\text { MAHASISWA }\end{array}$ & WAKTU & $\begin{array}{c}\text { MEDIA } \\
\text { DAN ALAT } \\
\text { PENGAJAR } \\
\text { AN }\end{array}$ \\
\hline Pendahuluan & $\begin{array}{l}\text { 1. Mengucapkan } \\
\text { salam dan } \\
\text { menjelaskan } \\
\text { cakupan } \\
\text { materi } \\
\text { pertemuan ke- } \\
\text { 8; } \\
\text { 2. Menjelaskan } \\
\text { manfaat } \\
\text { materi } \\
\text { pertemuan ke- } \\
\text { 8; } \\
\text { 3. Relevansi } \\
\text { antara standart } \\
\text { kompetensi } \\
\text { dengan }\end{array}$ & $\begin{array}{l}\text { Memperhatikan } \\
\text { dan diskusi. }\end{array}$ & 10 Menit & $\begin{array}{l}\text { Laptop, } \\
\text { LCD/Infocus } \\
\text { dan White } \\
\text { board. }\end{array}$ \\
\hline
\end{tabular}




\begin{tabular}{|c|c|c|c|c|}
\hline & $\begin{array}{l}\text { kompetensi } \\
\text { dasar. }\end{array}$ & & & \\
\hline Penyajian & $\begin{array}{l}\text { 4. Menjelaskan } \\
\text { Keragaman } \\
\text { dan kesetaraan } \\
\text { sebagai } \\
\text { kekayaan } \\
\text { sosial budaya } \\
\text { Problematika } \\
\text { keragaman } \\
\text { dan kesetaraan }\end{array}$ & $\begin{array}{l}\text { Memperhatikan } \\
\text { dan diskusi. }\end{array}$ & 75 Menit & $\begin{array}{l}\text { Laptop, } \\
\text { LCD/Infocus } \\
\text { dan White } \\
\text { board. }\end{array}$ \\
\hline Penutup & $\begin{array}{l}\text { 5. Menunjuk } \\
\text { beberapa } \\
\text { mahasiswa } \\
\text { secara acak } \\
\text { untuk } \\
\text { menjawab } \\
\text { pertanyaan. }\end{array}$ & $\begin{array}{l}\text { Menjawab } \\
\text { pertanyaan, } \\
\text { memberikan } \\
\text { pendapat dan } \\
\text { memperhatikan }\end{array}$ & 15 Menit & \\
\hline
\end{tabular}

E. EVALUASI : 1. Jelaskan Keragaman dan kesetaraan sebagai kekayaan sosial budaya

2. Jelaskan Problematika keragaman dan kesetaraan 


\section{RENCANA PROGRAM PEMBELAJARAN}

(RPP)

$\begin{array}{ll}\text { Mata kuliah } & : \text { Ilmu Sosial Dasar } \\ \text { Kode Matakuliah } & : \text { MKK } 100107 \\ \text { sks } & : 2 \\ \text { Waktu pertemuan } & : 2 \times 50 \text { menit }\end{array}$

A. Tujuan

1. Standar Kompetensi

Mahasiswa dapat menjelaskan konsep-konsep social : dan budaya dasar

2. Kompetensi Dasar

B. Pokok Bahasan

C. Sub Pokok Bahasan
: Merumuskan fungsi, nilai, moral, dan hukum dalam upaya mendapatkan keadilan, ketertiban dan kesejahteraan masyarakat

: hakikat, fungsi, nilai, moral, dan hukum dalam upaya mendapatkan keadilan, ketertiban dan kesejahteraan masyarakat

: Mengkaji hakikat, fungsi, nilai, moral dan hukum dan Mengkaji keadilan, ketertiban dan kesejahteraan

D. Kegiatan Belajar Mengajar : Pertemuan ke 11 (sebelas)

\begin{tabular}{|c|c|c|c|c|}
\hline $\begin{array}{c}\text { TAHAP } \\
\text { KEGIATAN }\end{array}$ & $\begin{array}{l}\text { KEGIATAN } \\
\text { DOSEN }\end{array}$ & $\begin{array}{l}\text { KEGIATAN } \\
\text { MAHASISWA }\end{array}$ & WAKTU & $\begin{array}{c}\text { MEDIA DAN } \\
\text { ALAT } \\
\text { PENGAJARAN }\end{array}$ \\
\hline Pendahuluan & $\begin{array}{l}\text { 1. Mengucapkan } \\
\text { salam dan } \\
\text { menjelaskan } \\
\text { cakupan } \\
\text { materi } \\
\text { pertemuan ke- } \\
8 ; \\
\text { 2. Menjelaskan } \\
\text { manfaat } \\
\text { materi } \\
\text { pertemuan ke- } \\
\text { 8; }\end{array}$ & $\begin{array}{l}\text { Memperhatikan } \\
\text { dan diskusi. }\end{array}$ & 10 Menit & $\begin{array}{l}\text { Laptop, } \\
\text { LCD/Infocus dan } \\
\text { White board. }\end{array}$ \\
\hline
\end{tabular}




\begin{tabular}{|l|l|l|l|l|}
\hline & $\begin{array}{l}\text { 3. Relevansi } \\
\text { antara standart } \\
\text { kompetensi } \\
\text { dengan } \\
\text { kompetensi } \\
\text { dasar. }\end{array}$ & & & \\
\hline Penyajian & $\begin{array}{l}\text { 4. Menjelaskan i } \\
\text { hakikat, } \\
\text { fungsi, nilai, } \\
\text { moral dan } \\
\text { hukum dan } \\
\text { Mengkaji } \\
\text { keadilan, } \\
\text { ketertiban dan } \\
\text { kesejahteraan }\end{array}$ & $\begin{array}{l}\text { Memperhatikan } \\
\text { dan diskusi. }\end{array}$ & 75 Menit & $\begin{array}{l}\text { Laptop, } \\
\text { LCD/Infocus dan } \\
\text { White board. }\end{array}$ \\
\hline Penutup & $\begin{array}{l}\text { Menunjuk } \\
\text { beberapa } \\
\text { mahasiswa } \\
\text { secara acak } \\
\text { untuk } \\
\text { menjawab } \\
\text { pertanyaan. }\end{array}$ & $\begin{array}{l}\text { Menjawab } \\
\text { pertanyaan, } \\
\text { memberikan } \\
\text { pendapat dan } \\
\text { memperhatikan }\end{array}$ & 15 Menit & \\
& & & \\
\hline
\end{tabular}

E. EVALUASI : Jelaskan Mengkaji hakikat, fungsi, nilai, moral dan hukum? 


\section{RENCANA PROGRAM PEMBELAJARAN}

(RPP)

$\begin{array}{ll}\text { Mata kuliah } & : \text { Ilmu Sosial Dasar } \\ \text { Kode Matakuliah } & : \text { MKK } 100107 \\ \text { sks } & : 2 \\ \text { Waktu pertemuan } & : 2 \times 50 \text { menit }\end{array}$

A. Tujuan

1. Standar Kompetensi

Mahasiswa dapat menjelaskan konsep-konsep social : dan budaya dasar

2. Kompetensi Dasar

B. Pokok Bahasan

C. Sub Pokok Bahasan
: Merumuskan fungsi, nilai, moral, dan hukum dalam upaya mendapatkan keadilan, ketertiban dan kesejahteraan masyarakat

: hakikat, fungsi, nilai, moral, dan hukum dalam upaya mendapatkan keadilan, ketertiban dan kesejahteraan masyarakat

: Mengidentifikasi perwujudan masyarakat bermoral dan taat hukum serta problematika nilai, moral, dan hukum

D. Kegiatan Belajar Mengajar : Pertemuan ke 12 (duabelas)

\begin{tabular}{|c|c|c|c|c|}
\hline $\begin{array}{c}\text { TAHAP } \\
\text { KEGIATAN }\end{array}$ & $\begin{array}{l}\text { KEGIATAN } \\
\text { DOSEN }\end{array}$ & $\begin{array}{c}\text { KEGIATAN } \\
\text { MAHASISWA }\end{array}$ & WAKTU & $\begin{array}{c}\text { MEDIA DAN } \\
\text { ALAT } \\
\text { PENGAJARAN }\end{array}$ \\
\hline Pendahuluan & $\begin{array}{l}\text { 1. Mengucapkan } \\
\text { salam dan } \\
\text { menjelaskan } \\
\text { cakupan materi } \\
\text { pertemuan ke- } \\
\text { 8; } \\
\text { 2. Menjelaskan } \\
\text { manfaat materi } \\
\text { pertemuan ke- } \\
\text { 8; } \\
\text { 3. Relevansi } \\
\text { antara standart }\end{array}$ & $\begin{array}{l}\text { Memperhatikan } \\
\text { dan diskusi. }\end{array}$ & 10 Menit & $\begin{array}{l}\text { Laptop, } \\
\text { LCD/Infocus dan } \\
\text { White board. }\end{array}$ \\
\hline
\end{tabular}




\begin{tabular}{|c|c|c|c|c|}
\hline & $\begin{array}{l}\text { kompetensi } \\
\text { dengan } \\
\text { kompetensi } \\
\text { dasar. }\end{array}$ & & & \\
\hline Penyajian & $\begin{array}{l}\text { 4. Menjelaskan } \\
\text { perwujudan } \\
\text { masyarakat } \\
\text { bermoral dan } \\
\text { taat hukum } \\
\text { serta } \\
\text { problematika } \\
\text { nilai, moral, } \\
\text { dan hukum }\end{array}$ & $\begin{array}{l}\text { Memperhatikan } \\
\text { dan diskusi. }\end{array}$ & 75 Menit & $\begin{array}{l}\text { Laptop, } \\
\text { LCD/Infocus dan } \\
\text { White board. }\end{array}$ \\
\hline Penutup & $\begin{array}{l}\text { 5. Menunjuk } \\
\text { beberapa } \\
\text { mahasiswa } \\
\text { secara acak } \\
\text { untuk } \\
\text { menjawab } \\
\text { pertanyaan. }\end{array}$ & $\begin{array}{l}\text { Menjawab } \\
\text { pertanyaaan, } \\
\text { memberikan } \\
\text { pendapat dan } \\
\text { memperhatikan }\end{array}$ & 15 Menit & \\
\hline
\end{tabular}

E. EVALUASI : Jelaskan perwujudan masyarakat bermoral dan taat 


\section{RENCANA PROGRAM PEMBELAJARAN}

(RPP)

$\begin{array}{ll}\text { Mata kuliah } & : \text { Ilmu Sosial Dasar } \\ \text { Kode Matakuliah } & : \text { MKK } 100107 \\ \text { sks } & : 2 \\ \text { Waktu pertemuan } & : 2 \times 50 \text { menit }\end{array}$

A. Tujuan

1. Standar Kompetensi

Mahasiswa dapat menjelaskan konsep-konsep social

: dan budaya dasar

2. Kompetensi Dasar

: Menguraikan hakikat dan makna sains, teknologi, dan seni, dan dampak dan pemanfaatan teknologi di Indonesia

B. Pokok Bahasan

: hakikat dan makna sains, teknologi, dan seni, dan dampak dan pemanfaatan teknologi di Indonesia

C. Sub Pokok Bahasan $\quad$ : Hakikat dan makna sains, teknologi, dan seni bagi manusia

Dampak penyalahgunaan IPTEKS pada kehidupan sosbud serta Problematika pemanfaatan IPTEKS di Indonesia

D. Kegiatan Belajar Mengajar : Pertemuan ke 13 (tiga belas)

\begin{tabular}{|c|c|c|c|c|}
\hline $\begin{array}{c}\text { TAHAP } \\
\text { KEGIATAN }\end{array}$ & $\begin{array}{l}\text { KEGIATAN } \\
\text { DOSEN }\end{array}$ & $\begin{array}{c}\text { KEGIATAN } \\
\text { MAHASISWA }\end{array}$ & WAKTU & $\begin{array}{c}\text { MEDIA DAN } \\
\text { ALAT } \\
\text { PENGAJARAN }\end{array}$ \\
\hline Pendahuluan & $\begin{array}{l}\text { 1. Mengucapkan } \\
\text { salam dan } \\
\text { menjelaskan } \\
\text { cakupan } \\
\text { materi } \\
\text { pertemuan ke- } \\
\text { 8; } \\
\text { 2. Menjelaskan } \\
\text { manfaat } \\
\text { materi } \\
\text { pertemuan ke- } \\
\text { 8; } \\
\text { 3. Relevansi }\end{array}$ & $\begin{array}{l}\text { Memperhatikan } \\
\text { dan diskusi. }\end{array}$ & 10 Menit & $\begin{array}{l}\text { Laptop, } \\
\text { LCD/Infocus dan } \\
\text { White board. }\end{array}$ \\
\hline
\end{tabular}




\begin{tabular}{|c|c|c|c|c|}
\hline & $\begin{array}{l}\text { antara standart } \\
\text { kompetensi } \\
\text { dengan } \\
\text { kompetensi } \\
\text { dasar. } \\
\end{array}$ & & & \\
\hline Penyajian & $\begin{array}{l}\text { 4. Menjelaskan } \\
\text { dampak } \\
\text { penyalahguna } \\
\text { an IPTEKS } \\
\text { pada } \\
\text { kehidupan } \\
\text { sosbud serta } \\
\text { Problematika } \\
\text { pemanfaatan } \\
\text { IPTEKS di } \\
\text { Indonesia }\end{array}$ & $\begin{array}{l}\text { Memperhatikan } \\
\text { dan diskusi. }\end{array}$ & 75 Menit & $\begin{array}{l}\text { Laptop, } \\
\text { LCD/Infocus dan } \\
\text { White board. }\end{array}$ \\
\hline Penutup & $\begin{array}{l}\text { 5. Menunjuk } \\
\text { beberapa } \\
\text { mahasiswa } \\
\text { secara acak } \\
\text { untuk } \\
\text { menjawab } \\
\text { pertanyaan. }\end{array}$ & $\begin{array}{l}\text { Menjawab } \\
\text { pertanyaaan, } \\
\text { memberikan } \\
\text { pendapat dan } \\
\text { memperhatikan }\end{array}$ & 15 Menit & \\
\hline
\end{tabular}

E. EVALUASI : Jelaskan dampak penyalahgunaan IPTEKS pada kehidupan 


\section{RENCANA PROGRAM PEMBELAJARAN}

$(\mathbf{R P P})$

$\begin{array}{ll}\text { Mata kuliah } & : \text { Ilmu Sosial Dasar } \\ \text { Kode Matakuliah } & : \text { MKK } 100107 \\ \text { sks } & : 2 \\ \text { Waktu pertemuan } & : 2 \times 50 \text { menit }\end{array}$

A. Tujuan

1. Standar Kompetensi Mahasiswa dapat menjelaskan konsep-konsep : social dan budaya dasar

2. Kompetensi Dasar $\quad$ : Menjelaskan hakikat dan makna lingkungan bagi kesejahteraan
B. Pokok Bahasan : hakikat dan makna lingkungan bagi kesejahteraan
C. Sub Pokok Bahasan : Hakikat dan makna lingkungan bagi manusia dan Kualitas penduduk dan lingkungan terhadap kesejahteraan

D. Kegiatan Belajar Mengajar : Pertemuan ke 14 (empat belas)

\begin{tabular}{|c|c|c|c|c|}
\hline $\begin{array}{c}\text { TAHAP } \\
\text { KEGIATAN }\end{array}$ & $\begin{array}{l}\text { KEGIATAN } \\
\text { DOSEN }\end{array}$ & $\begin{array}{c}\text { KEGIATAN } \\
\text { MAHASISWA }\end{array}$ & WAKTU & $\begin{array}{c}\text { MEDIA DAN } \\
\text { ALAT } \\
\text { PENGAJARAN }\end{array}$ \\
\hline Pendahuluan & $\begin{array}{l}\text { 1. Mengucapkan } \\
\text { salam dan } \\
\text { menjelaskan } \\
\text { cakupan } \\
\text { materi } \\
\text { pertemuan ke- } \\
\text { 8; } \\
\text { 2. Menjelaskan } \\
\text { manfaat } \\
\text { materi } \\
\text { pertemuan ke- } \\
\text { 8; } \\
\text { 3. Relevansi } \\
\text { antara standart } \\
\text { kompetensi } \\
\text { dengan } \\
\text { kompetensi }\end{array}$ & $\begin{array}{l}\text { Memperhatikan } \\
\text { dan diskusi. }\end{array}$ & 10 Menit & $\begin{array}{l}\text { Laptop, } \\
\text { LCD/Infocus dan } \\
\text { White board. }\end{array}$ \\
\hline
\end{tabular}




\begin{tabular}{|c|c|c|c|c|}
\hline & dasar. & & & \\
\hline Penyajian & $\begin{array}{l}\text { 4. Menjelaskan } \\
\text { Hakikat dan } \\
\text { makna } \\
\text { lingkungan } \\
\text { bagi manusia } \\
\text { dan Kualitas } \\
\text { penduduk dan } \\
\text { lingkungan } \\
\text { terhadap } \\
\text { kesejahteraan }\end{array}$ & $\begin{array}{l}\text { Memperhatikan } \\
\text { dan diskusi. }\end{array}$ & 75 Menit & $\begin{array}{l}\text { Laptop, } \\
\text { LCD/Infocus dan } \\
\text { White board. }\end{array}$ \\
\hline Penutup & $\begin{array}{l}\text { 5. Menunjuk } \\
\text { beberapa } \\
\text { mahasiswa } \\
\text { secara acak } \\
\text { untuk } \\
\text { menjawab } \\
\text { pertanyaan. }\end{array}$ & $\begin{array}{l}\text { Menjawab } \\
\text { pertanyaan, } \\
\text { memberikan } \\
\text { pendapat dan } \\
\text { memperhatikan }\end{array}$ & 15 Menit & \\
\hline
\end{tabular}

E. EVALUASI : Jelaskan dan Kualitas penduduk dan lingkungan terhadap kesejahteraan 


\section{RENCANA PROGRAM PEMBELAJARAN}

(RPP)

$\begin{array}{ll}\text { Mata kuliah } & : \text { Ilmu Sosial Dasar } \\ \text { Kode Matakuliah } & : \text { MKK } 100107 \\ \text { sks } & : 2\end{array}$

Waktu pertemuan $: 2 \times 50$ menit

D. Tujuan

1. Standar Kompetensi

2. Kompetensi Dasar

E. Pokok Bahasan

F. Sub Pokok Bahasan
Mahasiswa dapat menjelaskan konsep-konsep social : dan budaya dasar

: Menguraikan hakikat dan makna lingkungan bagi kesejahteraan

: hakikat dan makna lingkungan bagi kesejahteraan

: Problema lingkungan sosial budaya dan Isu-isu penting tentang lintas budaya dan bangsa

D. Kegiatan Belajar Mengajar : Pertemuan ke 15 (lima belas)

\begin{tabular}{|c|c|c|c|c|}
\hline $\begin{array}{c}\text { TAHAP } \\
\text { KEGIATAN }\end{array}$ & $\begin{array}{l}\text { KEGIATAN } \\
\text { DOSEN }\end{array}$ & $\begin{array}{c}\text { KEGIATAN } \\
\text { MAHASISWA }\end{array}$ & WAKTU & $\begin{array}{c}\text { MEDIA DAN } \\
\text { ALAT } \\
\text { PENGAJARAN }\end{array}$ \\
\hline Pendahuluan & $\begin{array}{l}\text { 1. Mengucapkan } \\
\text { salam dan } \\
\text { menjelaskan } \\
\text { cakupan materi } \\
\text { pertemuan ke- } \\
8 \text {; } \\
\text { 2. Menjelaskan } \\
\text { manfaat materi } \\
\text { pertemuan ke- } \\
\text { 8; } \\
\text { 3. Relevansi } \\
\text { antara standart } \\
\text { kompetensi } \\
\text { dengan } \\
\text { kompetensi } \\
\text { dasar. }\end{array}$ & $\begin{array}{l}\text { Memperhatikan } \\
\text { dan diskusi. }\end{array}$ & 10 Menit & $\begin{array}{l}\text { Laptop, } \\
\text { LCD/Infocus dan } \\
\text { White board. }\end{array}$ \\
\hline Penyajian & $\begin{array}{l}\text { 4. Menjelaskan } \\
\text { Problema } \\
\text { lingkungan } \\
\text { sosial budaya } \\
\text { dan Isu-isu } \\
\end{array}$ & $\begin{array}{l}\text { Memperhatikan } \\
\text { dan diskusi. }\end{array}$ & 75 Menit & $\begin{array}{l}\text { Laptop, } \\
\text { LCD/Infocus dan } \\
\text { White board. }\end{array}$ \\
\hline
\end{tabular}




\begin{tabular}{|l|l|l|l|l|}
\hline & $\begin{array}{l}\text { penting tentang } \\
\text { lintas budaya } \\
\text { dan bangsa }\end{array}$ & & \\
\hline Penutup & $\begin{array}{l}\text { 5. Menunjuk } \\
\text { beberapa } \\
\text { mahasiswa } \\
\text { secara acak } \\
\text { untuk } \\
\text { menjawab } \\
\text { pertanyaan. }\end{array}$ & $\begin{array}{l}\text { Menjawab } \\
\text { pertanyaan, } \\
\text { memberikan } \\
\text { pendapat dan } \\
\text { memperhatikan }\end{array}$ & & \\
& & & \\
& & & \\
\hline
\end{tabular}

E. EVALUASI : $\quad 1$. Jelaskan problema lingkungan sosial budaya

2. Jelaskan dan Isu-isu penting tentang lintas budaya dan bangsa 


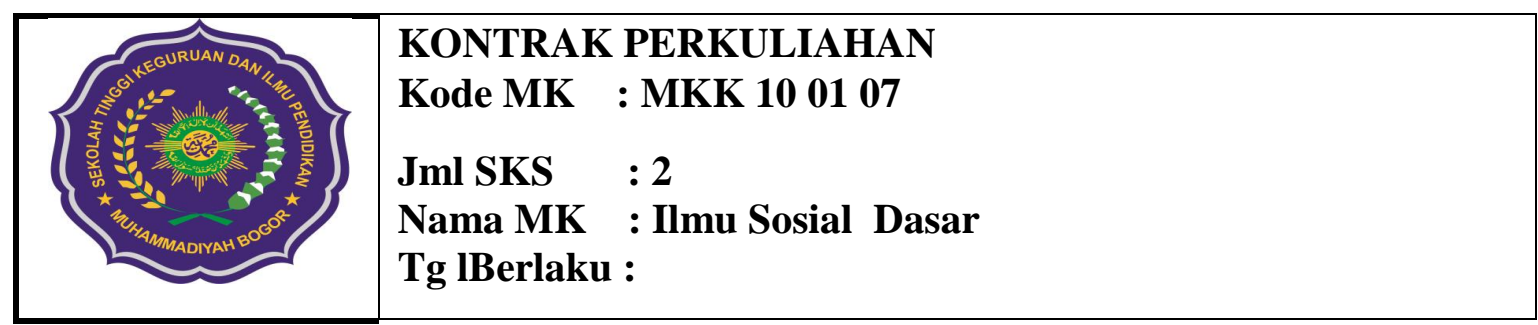

A. Identitas

\begin{tabular}{|l|l|}
\hline $\begin{array}{l}\text { Objective [ TIU ] } \\
\text { (STANDAR } \\
\text { KOMPETENSI) }\end{array}$ & \\
\hline $\begin{array}{l}\text { Jml Jam kuliah } \\
\text { dalam seminggu }\end{array}$ & $1 \times 100$ menit tatap muka, \\
\hline $\begin{array}{l}\text { Jml Jam kegiatan } \\
\text { laboratorium }\end{array}$ & x. 100 menit persiapan dan pekerjaan di luar kelas \\
\hline Dosen Penyusun & Nama : Wahyu Bagja Sulfemi, SS. \\
\hline
\end{tabular}

B. Level Taksonomi

\begin{tabular}{|c|c|c|c|c|c|}
\hline \multirow[t]{6}{*}{$\begin{array}{l}\text { Aspek } \\
\text { Koginitf }\end{array}$} & Knowledge & $\sqrt{ }$ & \multirow[t]{6}{*}{$\begin{array}{l}\text { Aspek } \\
\text { Afektif }\end{array}$} & $\begin{array}{l}\text { Receiving } \\
\text { Phenomena }\end{array}$ & \\
\hline & Comprehension & $\sqrt{ }$ & & $\begin{array}{l}\text { Responding to } \\
\text { Phenomena }\end{array}$ & \\
\hline & Application & & & Valuing & $\sqrt{ }$ \\
\hline & Analysis & & & Organization & \\
\hline & Synthesis & & & Characterization & \\
\hline & Evaluation & & & & \\
\hline \multirow{5}{*}{$\begin{array}{l}\text { Aspek } \\
\text { Psikomotorik }\end{array}$} & Perception & & & & \\
\hline & Preparation & & & & \\
\hline & Mechanization & & & & \\
\hline & Motorization & & & & \\
\hline & Creativity & & & & \\
\hline
\end{tabular}

C. Keterampilan Profesi (PersyaratanBisnis / Industri)

\begin{tabular}{|l|l|}
\hline Aspek & $\begin{array}{l}\text { Kemampuan } \\
\text { Ketrampilan }\end{array}$ \\
\hline Menulis & $15 \%$ \\
\hline Bertanya & $10 \%$ \\
\hline Presentasi \& Diskusi & $50 \%$ \\
\hline $\begin{array}{l}\text { Komunikasi \& kerjasama dalam } \\
\text { Tim }\end{array}$ & $15 \%$ \\
\hline Keputusan & $10 \%$ \\
\hline
\end{tabular}

D. Materi dan Pelaksanaan

\begin{tabular}{|l|l|l|}
\hline Pertemuan & Sub Pokok Bahasan & Materi Bahasan
\end{tabular}




\begin{tabular}{|c|c|c|}
\hline $\mathbf{K e}$ & & \\
\hline 1 & $\begin{array}{l}\text { Hakikat dan ruang lingkup } \\
\text { ISD, dan ISD sebagai } \\
\text { alternatif solusi problem sosbu }\end{array}$ & $\begin{array}{l}\text { 1. Hakikat dan ruang } \\
\text { lingkup ISD } \\
\text { 2. ISD sebagai alternatif } \\
\text { solusi problem social } \\
\text { budaya }\end{array}$ \\
\hline 2 & $\begin{array}{l}\text { Hakikat manusia sebagai } \\
\text { mahluk budaya dan Apresiasi } \\
\text { kemanusiaan dan kebudayaan }\end{array}$ & $\begin{array}{l}\text { 1. Hakikat manusia } \\
\text { 2. Pengertian kebudayaan } \\
\text { 3. Hakikat manusia } \\
\text { 4. sebagai mahluk budaya } \\
\text { 5. Apresiasi kemanusiaan } \\
\text { dan kebudayaan }\end{array}$ \\
\hline 3 & $\begin{array}{l}\text { Etika dan Estetika budaya, } \\
\text { Konsep-konsep dasar manusia } \\
\text { dan Problema kebudayaan }\end{array}$ & $\begin{array}{l}\text { 1. Pengertian Etika dan } \\
\text { Estetika } \\
\text { 2. Konsep-konsep dasar } \\
\text { manusia } \\
\text { 3. Problema kebudayaan }\end{array}$ \\
\hline 4 & $\begin{array}{l}\text { Hakikat manusia sebagai } \\
\text { individu dan mahluk sosial dan } \\
\text { Fungsi dan peran manusia } \\
\text { sebagai individu dan mahluk } \\
\text { sosial }\end{array}$ & $\begin{array}{l}\text { 1. Pengertian individu dan } \\
\text { 2. individu mahluk sosial } \\
\text { 3. Fungsi dan peran manusia } \\
\text { sebagai individu dan } \\
\text { mahluk sosial }\end{array}$ \\
\hline 5 & $\begin{array}{l}\text { Dinamika interaksi sosial dan } \\
\text { Dilema kepentingan individu } \\
\text { dan masyarakat }\end{array}$ & $\begin{array}{l}\text { 1. interaksi sosial } \\
\text { 2. Dinamika interaksi sosial } \\
\text { 3. Pengertian Masyarakat } \\
\text { 4. Dilema kepentingan } \\
\text { individu dan masyarakat }\end{array}$ \\
\hline 6 & $\begin{array}{l}\text { Hakikat peradaban Mahluk } \\
\text { beradab dan masyarakat } \\
\text { beradab }\end{array}$ & $\begin{array}{l}\text { 1. Hakikat peradaban } \\
\text { 2. Mahluk beradab dan } \\
\text { 3. masyarakat beradab } \\
\text { 4. Mahluk beradab da } \\
\text { masyarakat beradab }\end{array}$ \\
\hline 7 & $\begin{array}{l}\text { Evolusi budaya dan wujud } \\
\text { peradaban Dinamika peradaban } \\
\text { global serta Problematika } \\
\text { peradaban }\end{array}$ & $\begin{array}{l}\text { 1. Evolusi budaya dan wujud } \\
\text { peradaban } \\
\text { 2. Dinamika peradaban } \\
\text { global } \\
\text { 3. Problematika peradaban }\end{array}$ \\
\hline 8 & $\begin{array}{ll}\text { UJIAN } & \text { TENGAH } \\
\text { SEMESTER } & \end{array}$ & \\
\hline 9 & $\begin{array}{l}\text { Hakikat keragaman dan } \\
\text { kesetaraanmanusia dan } \\
\text { Kemajemukan dalam dinamika } \\
\text { sosial budaya }\end{array}$ & $\begin{array}{l}\text { 1. Hakikat keragaman } \\
\text { 2. kesetaraanmanusia } \\
\text { 3. Kemajemukan dalam } \\
\text { dinamika sosial budaya }\end{array}$ \\
\hline 10 & $\begin{array}{l}\text { Keragaman dan kesetaraan } \\
\text { sebagai kekayaan sosial }\end{array}$ & $\begin{array}{l}\text { 1. Keragaman dan kesetaraan } \\
\text { sebagai kekayaan sosial }\end{array}$ \\
\hline
\end{tabular}




\begin{tabular}{|c|c|c|}
\hline & $\begin{array}{l}\text { budaya Problematika } \\
\text { keragaman dan kesetaraan }\end{array}$ & $\begin{array}{ll}\text { budaya } \\
\text { 2. Problematika keragaman } \\
\text { dan kesetaraan }\end{array}$ \\
\hline 11 & $\begin{array}{l}\text { Mengkaji hakikat, fungsi, nilai, } \\
\text { moral dan hukum dan } \\
\text { Mengkaji keadilan, ketertiban } \\
\text { dan kesejahteraan }\end{array}$ & $\begin{array}{l}\text { 1. Hakikat fungsi } \\
\text { 2. Hakikat nilai } \\
\text { 3. Hakikat moral dan hukum } \\
\text { 4. Pengertian Keadilan, } \\
\text { 5. Pengertian ketertiban dan } \\
\text { kesejahteraan }\end{array}$ \\
\hline 12 & $\begin{array}{l}\text { Mengidentifikasi perwujudan } \\
\text { masyarakat bermoral dan taat } \\
\text { hukum serta problematika } \\
\text { nilai, moral, dan hukum }\end{array}$ & $\begin{array}{l}\text { 1. Perwujudan masyarakat } \\
\text { bermoral } \\
\text { 2. Perwujudan masyarakat } \\
\text { taat hukum } \\
\text { 3. Problematika nilai, dan } \\
\text { moral } \\
\text { 4. Problematika hukum }\end{array}$ \\
\hline 13 & $\begin{array}{l}\text { Hakikat dan makna sains, } \\
\text { teknologi, dan seni bagi } \\
\text { manusia serta Dampak } \\
\text { penyalahgunaan IPTEKS pada } \\
\text { kehidupan sosbud serta } \\
\text { Problematika pemanfaatan } \\
\text { IPTEKS di Indonesia }\end{array}$ & $\begin{array}{l}\text { 1. Hakikat makna sains, } \\
\text { 2. Hakikat teknologi } \\
\text { 3. Hakikat dan seni bagi } \\
\text { manusia } \\
\text { 4. Dampak penyalahgunaan } \\
\text { IPTEKS pada kehidupan } \\
\text { sosbud } \\
\text { 5. Problematika pemanfaatan } \\
\text { IPTEKS di Indonesia }\end{array}$ \\
\hline 14 & $\begin{array}{l}\text { Hakikat dan makna lingkungan } \\
\text { bagi manusia dan Kualitas } \\
\text { penduduk dan lingkungan } \\
\text { terhadap kesejahteraan }\end{array}$ & $\begin{array}{l}\text { 1. Hakikat dan makna } \\
\text { lingkungan bagi manusia } \\
\text { 2. Kualitas penduduk dan } \\
\text { lingkungan terhadap } \\
\text { kesejahteraan }\end{array}$ \\
\hline 15 & $\begin{array}{l}\text { Problema lingkungan sosial } \\
\text { budaya dan Isu-isu penting } \\
\text { tentang lintas budaya dan } \\
\text { bangsa }\end{array}$ & $\begin{array}{l}\text { 1. Problema lingkungan } \\
\text { sosial budaya } \\
\text { 2. Isu-isu penting tentang } \\
\text { lintas budaya dan bangsa }\end{array}$ \\
\hline 16 & UJIAN AKHIR SEMESTER & \\
\hline
\end{tabular}

E. Metode Penyampaian Materi/Sistem Perkuliahan

1. Ceramah dan tanya jawab;

2. Presentasi dan diskusi

3. Penugasan;

\section{F. Rencana Tugas Mandiri}

\begin{tabular}{|l|l|l|}
\hline Tugas Ke & Jenis *) & Isi Tugas \\
\hline Kesatu & Individu & $\begin{array}{l}\text { Menjelaskan ISD sebagai alternatif solusi problem } \\
\text { social budaya }\end{array}$ \\
\hline
\end{tabular}




\begin{tabular}{|c|c|c|}
\hline Kedua & Individu & Menjelaskan manusia sebagai mahluk budaya \\
\hline Ketiga & Individu & $\begin{array}{l}\text { Makalah Etika dan Estetika budaya, Konsep-konsep } \\
\text { dasar manusia dan Problema kebudayaan }\end{array}$ \\
\hline Keempat & Individu & $\begin{array}{l}\text { Menjelaskan Hakikat manusia sebagai individu dan } \\
\text { mahluk sosial dan Fungsi dan peran manusia sebagai } \\
\text { individu dan mahluk sosial }\end{array}$ \\
\hline Kelima & Individu & $\begin{array}{l}\text { Menjelaskan Dinamika interaksi sosial dan Dilema } \\
\text { kepentingan individu dan masyarakat }\end{array}$ \\
\hline Keenam & Individu & $\begin{array}{l}\text { Menjelaskan Hakikat peradaban Mahluk beradab dan } \\
\text { masyarakat beradab }\end{array}$ \\
\hline Ketujuh & Individu & $\begin{array}{l}\text { Menjelaskan Evolusi budaya dan wujud peradaban } \\
\text { Dinamika peradaban global serta Problematika } \\
\text { peradaban }\end{array}$ \\
\hline Kedelapan & Ujian Teng & Semester (UTS) \\
\hline Kesembilan & Individu & $\begin{array}{l}\text { Menjelaskan Hakikat keragaman, kesetaraanmanusia } \\
\text { dan Kemajemukan dalam dinamika sosial }\end{array}$ \\
\hline Kesepuluh & Kelompok & $\begin{array}{l}\text { Menjelaskan Mengkaji hakikat, fungsi, nilai, moral } \\
\text { dan hukum dan Mengkaji keadilan, ketertiban dan } \\
\text { kesejahteraan }\end{array}$ \\
\hline Kesebelas & Individu & $\begin{array}{l}\text { Menjelaskan Mengidentifikasi perwujudan } \\
\text { masyarakat bermoral dan taat hukum serta } \\
\text { problematika nilai, moral, dan hukum }\end{array}$ \\
\hline Keduabelas & Kelompok & $\begin{array}{l}\text { Menjelaskan Hakikat dan makna sains, teknologi, dan } \\
\text { seni bagi manusia }\end{array}$ \\
\hline Ketigabelas & Kelompok & $\begin{array}{l}\text { Menjelaskan Dampak penyalahgunaan IPTEKS pada } \\
\text { kehidupan sosbud serta Problematika pemanfaatan } \\
\text { IPTEKS di Indonesia }\end{array}$ \\
\hline Keempatbelas & Kelompok & $\begin{array}{l}\text { Menjelaskan Hakikat dan makna lingkungan bagi } \\
\text { manusia dan Kualitas penduduk dan lingkungan } \\
\text { terhadap kesejahteraan }\end{array}$ \\
\hline Kelimabelas & Individu & $\begin{array}{l}\text { Menjelaskan Problema lingkungan sosial budaya dan } \\
\text { Isu-isu penting tentang lintas budaya dan bangsa }\end{array}$ \\
\hline Keenambelas & \multicolumn{2}{|c|}{ Ujian Akhir Semester (UAS) } \\
\hline
\end{tabular}

*) Diisi : kelompok / individ

\section{H. Rencana Ujian}

1. UJIAN TENGAH SEMESTER

2. UJIAN AKHIR SEMESTER

3. Ketentuan Ujian :

Mahasiswa dapat mengikuti ujian dengan kehadiran dalam kuliah minimal $75 \%$

\section{Penilaian}




\begin{tabular}{|l|c|c|}
\hline Aspek Penilaian & Komposisi Penilaian & Prosentase \\
\hline Kehadiran & $10 \%$ & $5-15 \%$ \\
\hline Tugas Mandiri & $10 \%$ & $5-15 \%$ \\
\hline Tugaskelompok & $10 \%$ & $5-15 \%$ \\
\hline Hasil UTS & $30 \%$ & $5-50 \%$ \\
\hline Hasil UAS & $40 \%$ & $5-50 \%$ \\
\hline & Total : & $\mathbf{1 0 0} \%$ \\
\hline
\end{tabular}




\section{RANCANGAN TUGAS PEMBELAJARAN \\ PROGRAM STUDI TEKNIK INFORMATIKA \\ TAHUN AKADEMIK 2007 - 2008}

\begin{tabular}{|c|c|c|}
\hline MATA KULIAH & : & Ilmu Sosial Dasar \\
\hline KODE MATA KULIAH & . & MKK 100107 \\
\hline K S & & 2 \\
\hline $\begin{array}{l}\text { PENANGGUNG JAWAB } \\
\text { MK. }\end{array}$ & : & Wahyu Bagja Sulfemi, SS. \\
\hline DESKRIPSI SINGKAT & & $\begin{array}{l}\text { Mata kuliah Ilmu Sosial Dasaradalah salah satu dari } \\
\text { mata kuliah kelompok Matakuliah Berkehidupan } \\
\text { Bermasyarakat (MBB) di perguruan tinggi. } \\
\text { Matakuliah ISD mengetengahkan pengetahuan dasar } \\
\text { tentang konsep-konsep manusia, konsep-konsep } \\
\text { kebudayaan, konsep-konsep sosiologi, konsep- } \\
\text { konsep nilai, moral, dan hukum, dan konsep-konsep } \\
\text { sains, teknoloi, seni, dan lingkungan }\end{array}$ \\
\hline STANDAR KOMPETENSI & & $\begin{array}{l}\text { Setelah mengikuti matakuliah ini mahasiswa dapat } \\
\text { menjelaskan konsep-konsep social dan budaya dasar }\end{array}$ \\
\hline
\end{tabular}

\section{DESKRIPSI TUGAS - 1}

1. TUJUAN TUGAS $\quad$ : Mahasiswa dapat Menjelaskan dan Merumuskan manusia sebagai mahluk berbudaya, beretika, dan berestetika Merumuskan dan mengespresikan manusia sebagai mahluk berbudaya, beretika, dan berestetika.

2. URAIAN TUGAS $\quad$ : Membuat laporan berupa penjelasan berbagai budaya dari beberapa daerah

3. KRITERIA PENILAIAN

: Penilaian dilakukan berdasarkan lembar kerja yang dibuat dan diserahkan berdasarkan hasil pemahaman mahasiswa.

\section{DESKRIPSI TUGAS - 2}

1. TUJUAN TUGAS : Mahasiswa dapat mendefinisikan hakikat manusia sebagai individu dan mahluk sosial

2. URAIAN TUGAS : Berupa tes uraian dari dosen mengenai definisi indivu dan mahluk sosial

3. KRITERIA : Penilaian dilakukan berdasarkan lembar kerja yang dibuat PENILAIAN 
dan diserahkan berdasarkan hasil pemahaman mahasiswa.

\section{DESKRIPSI TUGAS - 3}

1. TUJUAN TUGAS : Mahasiswa mampu menjelaskan manusia dan peradaban, dan dinamika peradaban global

2. URAIAN TUGAS : Menjelaskan manusia dan peradaban, dan dinamika peradaban global

3. KRITERIA PENILAIAN

\section{DESKRIPSI TUGAS - 4}

1. TUJUAN TUGAS

2. URAIAN TUGAS

3. KRITERIA PENILAIAN

\section{DESKRIPSI TUGAS - 5}

1. TUJUAN TUGAS

: Mahasiswa dapat merumuskan hakikat, fungsi, nilai, moral, dan hukum dalam upaya mendapatkan keadilan, ketertiban dan kesejahteraan masyarakat

2. URAIAN TUGAS : Merumuskan hakikat, fungsi, nilai, moral, dan hukum dalam upaya mendapatkan keadilan, ketertiban dan kesejahteraan masyarakat dari berbagai sumber dengan diberikan tugas esay

3. KRITERIA PENILAIAN

: Penilaian dilakukan berdasarkan lembar kerja yang dibuat dan diserahkan berdasarkan hasil pemahaman mahasiswa.

\section{DESKRIPSI TUGAS - 6}

1. TUJUAN TUGAS : Mahasiswa mampu menguraikan hakikat dan makna sains, teknologi, dan seni, dan dampak dan pemanfaatan teknologi di Indonesia 
2. URAIAN TUGAS : Berupa tes uraian yang diberikan mengenai sains, teknologi, dan seni, dan dampak dan pemanfaatan teknologi di Indonesia

3. KRITERIA

: Penilaian dilakukan berdasarkan lembar kerja yang dibuat PENILAIAN dan diserahkan berdasarkan hasil pemahaman mahasiswa.

\section{DESKRIPSI TUGAS - 7}

1. TUJUAN TUGAS : Mahasiswa mampu menguraian hakikat dan makna lingkungan bagi kesejahteraan

2. URAIAN TUGAS $\quad$ : Membuat makalah mengenai lingkungan hidup

3. KRITERIA : Penilaian dilakukan berdasarkan laporan kerja yang PENILAIAN dibuat secara kelompok. 


\author{
RENCANA EVALUASI
}

PROSES PEMBELAJARAN

Mata Kuliah

Kode Mata

Kuliah/SKS/Semester

Program Studi

Waktu Pelaksanaan

Tujuan Evaluasi
: ILMU SOSIAL DASAR

: MKK 005/2SKS/2

: ADMINISTRASI PENDIDIKAN

: UJIAN TENGAH SEMESTER DAN UJIAN

\section{AKHIR SEMESTER}

: 1. Mengukur persepsi mahasiswa terhadap kemampuan dosen dalam menyelenggarakan kegiatan pembelajaran;

2. Mengukur persepsi mahasiswa terhadap kualitas materi perkuliahan;

3. Mengukur persepsi mahasiswa terhadap sarana pendukung pelaksanaan perkuliahan;

4. Mencari masukan dari mahasiswa tentang masalah yang biasa muncul dalam mengikuti kegiatan pembelajaran. 
TABEL 1

RENCANA EVALUASI PROSES BELAJAR MENGAJAR

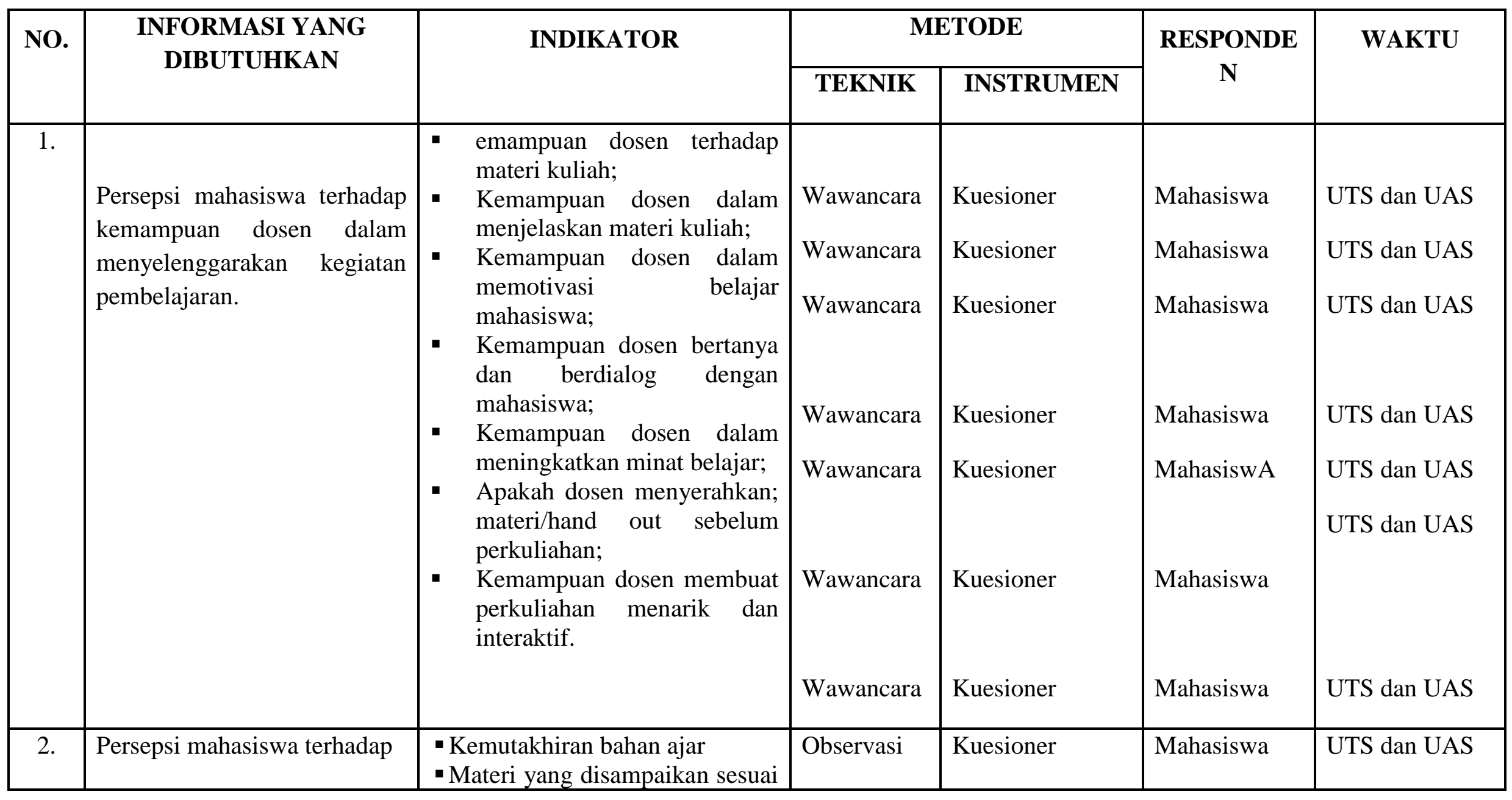




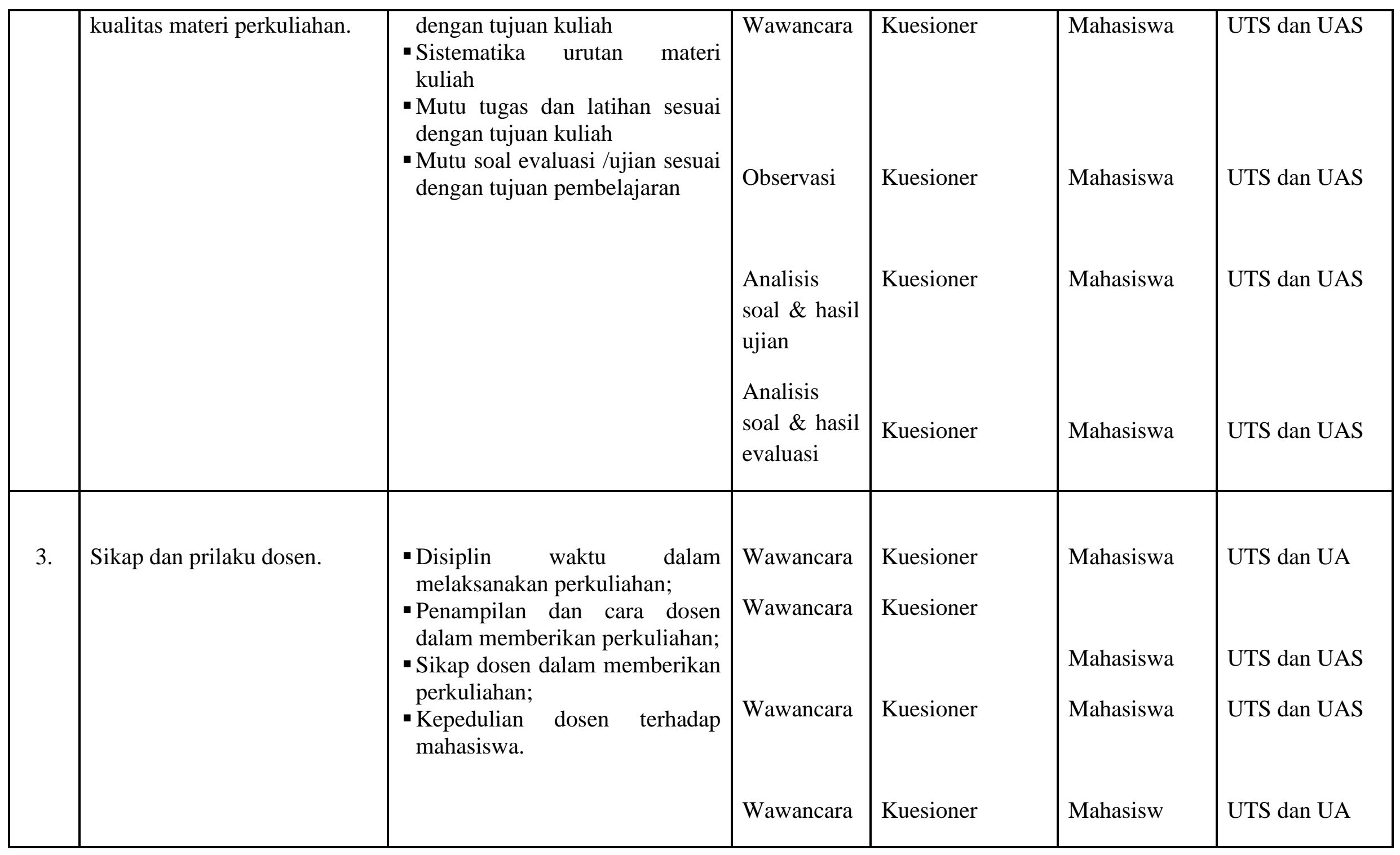




\begin{tabular}{|c|c|c|c|c|c|c|}
\hline 4. & $\begin{array}{l}\text { Penggunaan media dalam } \\
\text { pengajaran. }\end{array}$ & $\begin{array}{l}\text { - } \text { Ketepatan dalam memilih } \\
\text { media; } \\
\text { - Penguasaan dosen dalam } \\
\text { penggunaan media; } \\
\text { - Kreatif dalam pembuatan } \\
\text { media; } \\
\text { - Kesesuaian media dengan } \\
\text { tujuan matakuliah. }\end{array}$ & $\begin{array}{l}\text { Wawancara } \\
\text { Wawancara } \\
\text { Wawancara }\end{array}$ & $\begin{array}{l}\text { Kuesioner } \\
\text { Kuesioner } \\
\text { Kuesioner }\end{array}$ & $\begin{array}{l}\text { Mahasiswa } \\
\text { Mahasiswa } \\
\text { Mahasiswa }\end{array}$ & $\begin{array}{l}\text { UTS dan UAS } \\
\text { UTS dan UAS }\end{array}$ \\
\hline & & & Wawancara & Kuesioner & Mahasiswa & UTS dan UAS \\
\hline
\end{tabular}


TABEL 2

\section{DAFTAR PERTANYAAN UNTUK MENGUMPULKAN DATA}

\begin{tabular}{|c|c|c|c|c|}
\hline No. & $\begin{array}{r}\text { INFORMASI YA } \\
\text { DIBUTUHKAI }\end{array}$ & & INDIKATOR & PERTANYAAN \\
\hline 1. & $\begin{array}{l}\text { Persepsi mahasiswa } \\
\text { kemampuan dosen } \\
\text { menyelenggarakan } \\
\text { pembelajaran. }\end{array}$ & $\begin{array}{r}\text { terhadap } \\
\text { dalam } \\
\text { kegiatan }\end{array}$ & $\begin{array}{l}\text { - Kemampuan dosen terhadap materi } \\
\text { kuliah; } \\
\text { - Kemampuan dosen dalam } \\
\text { menjelaskan materi kuliah; } \\
\text { - Kemampuan dosen dalam } \\
\text { memotivasi belajar mahasiswa; } \\
\text { - Kemampuan dosen bertanya dan } \\
\text { berdialog dengan mahasiswa; } \\
\text { - Kemampuan dosen dalam } \\
\text { meningkatkan minat belajar; } \\
\text { - Apakah dosen menyerahkan; } \\
\text { materi/hand out sebelum } \\
\text { perkuliahan; } \\
\text { - Kemampuan dosen membuat } \\
\text { perkuliahan menarik dan interaktif. }\end{array}$ & $\begin{array}{l}\text { 1. Dosen menguasai materi kuliah } \\
\mathrm{SS}-\mathrm{S}-\mathrm{RR}-\mathrm{KS} \text { - TS } \\
\text { 2. Dosen menyampaikan materi dengan jelas } \\
\mathrm{SS}-\mathrm{S}-\mathrm{RR}-\mathrm{KS} \text { - TS } \\
\text { 3. Dosen memberi dorongan belajar kepada } \\
\text { mahasiswa } \\
\mathrm{SS}-\mathrm{S}-\mathrm{RR}-\mathrm{KS} \text { - TS } \\
\text { 4. Dosen bertanya dan berdialog } \\
\mathrm{SS}-\mathrm{S}-\mathrm{RR}-\mathrm{KS} \text { - TS } \\
\text { 5. Dosen mampu meningkat minat belajar } \\
\mathrm{SS}-\mathrm{S}-\mathrm{RR}-\mathrm{KS}-\mathrm{TS} \\
\text { 6. Dosem menyerahkanmateri kuliah } \\
\mathrm{SS}-\mathrm{S}-\mathrm{RR}-\mathrm{KS}-\mathrm{TS} \\
\text { 7. Dosen mampu membuat kuliah menarik } \\
\mathrm{SS}-\mathrm{S}-\mathrm{RR}-\mathrm{KS}-\mathrm{TS}\end{array}$ \\
\hline
\end{tabular}




\begin{tabular}{|c|c|c|c|}
\hline 2. & $\begin{array}{l}\text { Persepsi mahasiswa terhadap } \\
\text { kualitas materi perkuliahan }\end{array}$ & $\begin{array}{l}\text { - Kemutakhiran bahan ajar } \\
\text { - Materi yang disampaikan sesuai } \\
\text { dengan tujuan kuliah } \\
\text { - Sistematika urutan materi kuliah } \\
\text { - Mutu tugas dan latihan sesuai } \\
\text { dengan tujuan kuliah } \\
\text { - Mutu soal evaluasi /ujian sesuai } \\
\text { dengan tujuan pembelajaran }\end{array}$ & $\begin{array}{l}\text { 8. Bahan ajar yang disampaikan dosen } \\
\text { mutakhir } \\
\mathrm{SS}-\mathrm{S}-\mathrm{RR}-\mathrm{KS}-\mathrm{TS} \\
\text { 9. Dosen menyampaikan materi sesuai dengan } \\
\text { tujuan kuliah } \\
\mathrm{SS}-\mathrm{S}-\mathrm{RR}-\mathrm{KS}-\mathrm{TS} \\
\text { 10. Dosen menyampaikan materi sesuai dengan } \\
\text { urutan materi kuliah } \\
\mathrm{SS}-\mathrm{S}-\mathrm{RR}-\mathrm{KS}-\mathrm{TS} \\
\text { 11. Soal tugas dan latihan bermutu } \\
\mathrm{SS}-\mathrm{S}-\mathrm{RR}-\mathrm{KS}-\mathrm{TS} \\
\text { 12. Soal evaluasi dan ujian bermutu } \\
\mathrm{SS}-\mathrm{S}-\mathrm{RR}-\mathrm{KS}-\mathrm{TS}\end{array}$ \\
\hline 3. & Sikap dan prilaku dosen. & $\begin{array}{l}\text { - Disiplin waktu dalam } \\
\text { melaksanakan perkuliahan; } \\
\text { - Penampilan dan cara dosen dalam } \\
\text { memberikan perkuliahan; } \\
\text { - Sikap dosen dalam memberikan } \\
\text { perkuliahan; } \\
\text { - Kepedulian dosen terhadap } \\
\text { mahasiswa. }\end{array}$ & $\begin{array}{l}\text { 13. Apakah dosen hadir dan keluar tepat waktu } \\
\mathrm{SS}-\mathrm{S}-\mathrm{RR}-\mathrm{KS} \text { - TS } \\
\text { 14. Bagaimana penampilan dan cara berpakaian } \\
\text { dosen dalam menyampaikan kuliah } \\
\mathrm{SS}-\mathrm{S}-\mathrm{RR}-\mathrm{KS}-\mathrm{TS} \\
\text { 15. Bagaiman sikap dosen saat memberikan } \\
\text { perkuliahan } \\
\mathrm{SS}-\mathrm{S}-\mathrm{RR}-\mathrm{KS}-\mathrm{TS} \\
\text { 16. Apakah dosen perhatian dan peduli terhadap } \\
\text { mahasiswa } \\
\mathrm{SS}-\mathrm{S}-\mathrm{RR}-\mathrm{KS}-\mathrm{TS}\end{array}$ \\
\hline
\end{tabular}




\begin{tabular}{|c|c|c|c|c|}
\hline 4. & $\begin{array}{l}\text { Penggunaan } \\
\text { pengajaran. }\end{array}$ & media dalam & $\begin{array}{l}\text { - Ketepatan dalam memilih media; } \\
\text { - Penguasaan dosen dalam } \\
\text { penggunaan media; } \\
\text { - Kreatif dalam pembuatan media; } \\
\text { - Kesesuaian media dengan tujuan } \\
\text { matakuliah. }\end{array}$ & $\begin{array}{l}\text { 17. Apakah media yang digunakan sesuai } \\
\mathrm{SS}-\mathrm{S}-\mathrm{RR}-\mathrm{KS}-\mathrm{TS} \\
\text { 18. Apakah dosen menguasai media yang dipilih } \\
\mathrm{SS}-\mathrm{S}-\mathrm{RR}-\mathrm{KS}-\mathrm{TS} \\
\text { 19. Apakah dosen kreatif dalam menyiapkan } \\
\text { media pembelajaran } \\
\mathrm{SS}-\mathrm{S}-\mathrm{RR}-\mathrm{KS} \text { - TS } \\
\text { 20. Apakah media yang digunakan sesuai dengan } \\
\text { tujuan mata kuliah } \\
\mathrm{SS}-\mathrm{S}-\mathrm{RR}-\mathrm{KS}-\mathrm{TS}\end{array}$ \\
\hline
\end{tabular}

\section{Keterangan :}

SS: Sangat Setuju

\section{RR:Ragu-ragu}

TS : Tidak Setuju

\section{S: Setuju}

KS : Kurang Setuju 


$\begin{array}{ll}\text { MATA KULIAH (KODE) } & : \text { ILMU SOSIAL DASAR } \\ \text { PROGRAM STUDI } & : \text { ADMINISTRASI PENDIDIKAN } \\ \text { SEMESTER } & : 2 \\ \text { DOSEN } & : \text { WAHYU BAGJA SULFEMI, SS., MPD. }\end{array}$

TAHAP EVALUASI

Hasil evaluasi matakuliah pada akhir semester genap 2012/2013 diperoleh informasi sebagai berikut :

1. Mahasiswa lebih banyak senang mendengarkan;

2. Mahasiswa kurang berani dalam mengeluarkan pendapat dan mengajukan pertanyaan;

3. Mahasiswa kurang mampu dalam menganalisis permasalahan yang diberikan;

4. Mahasiswa dalam pengumpulan tugas sering tidak tepat waktu;

5. Hasil penilaian belajar mahasiswa hanya sedang;

6. Motivasi mahasiswa rendah mungkin karena beragamnya tingkat pemahaman.

Untuk mengatasi masalah tersebut maka dilakukan rekontruksi mata kuliah, antara lain dengan cara :

1. Mengubah strategi pembelajaran, yang semula lebih banyak ceramah, diubah menjadi sedikit ceramah dengan variasi tanya jawab, diskusi dan latihan;

2. Memperbanyak studi kasus dalam proses pembelajaran sehingga mahasiswa dapat mengasah kemampuan analisis dalam pemecahan permasalahan Ilmu social budaya

3. Menambah bahan ajar yang baru.

4. Memberikan motivasi kepada mahasiswa diawal perkuliahan disertai contoh secara real dalam bentuk multimedia dan kisah-kisah orang sukses. 


\section{Langkah 1 : Menentukan Standar Kompetensi}

Evaluasi menunjukkan bahwa standar kompetensi mata kuliah Ilmu Sosial Dasar belum tercapai secara optimal. Pencapaian kompetensi yang harus diperbaiki adalah menganalisa permasalahan dan cara pemecahan masalah yang dituangkan ke dalam bahasa pemograman. Berdasarkan hasil evaluasi standar kompetensi ditentukan dan dirumuskan kembali agar mahasiswa mengerti, memahami dan dapat membuat menjelaskan konsep-konsep social dan budaya dasar

\section{Langkah 2 : Menentukan Kompetensi Dasar}

Selanjutnya standar kompetensi dijabarkan dalam tujuan yang spesifik yaitu 14 kompetensi dasar yang harus dicapai.

Tabel 1. Kompetensi Dasar Mata Kuliah Ilmu Sosial Dasar.

\begin{tabular}{|r|c|}
\hline No. & \multicolumn{1}{|c|}{ Kompetensi Dasar } \\
\hline 1. & $\begin{array}{l}\text { Setelah mengikuti pembelajaran ini mahasiswa dapat menjelaskan hakikat dan } \\
\text { ruang lingkup ISD, dan ISD sebagai alternatif solusi problem social budaya }\end{array}$ \\
\hline 2. & $\begin{array}{l}\text { Setelah mengikuti pembelajaran ini mahasiswa dapat menjelaskan hakikat } \\
\text { manusia sebagai mahluk budaya dan apresiasi kemanusiaan dan kebudayaan }\end{array}$ \\
\hline 3. & $\begin{array}{l}\text { Setelah mengikuti pembelajaran ini mahasiswa dapat merumuskan etika dan } \\
\text { estetika budaya, serta Konsep-konsep dasar manusia dan Problema kebudayaan }\end{array}$ \\
\hline
\end{tabular}




\begin{tabular}{|c|c|}
\hline 4. & $\begin{array}{l}\text { Setelah mengikuti pembelajaran ini mahasiswa menjelaskan hakikat manusia } \\
\text { sebagai individu dan mahluk sosial dan Fungsi dan peran manusia sebagai }\end{array}$ \\
\hline 5. & $\begin{array}{l}\text { Setelah mengikuti pembelajaran ini mahasiswa dapat menjelakan inamika } \\
\text { interaksi sosial dan Dilema kepentingan individu dan masyarakat }\end{array}$ \\
\hline 6. & $\begin{array}{l}\text { Setelah mengikuti pembelajaran ini mahasiswa dapat menjelaskan hakikat } \\
\text { peradaban Mahluk beradab dan masyarakat beradab }\end{array}$ \\
\hline 7. & $\begin{array}{l}\text { Setelah mengikuti pembelajaran ini mahasiswa dapat menjelaskan } \\
\text { evolusi budaya dan wujud peradaban Dinamika peradaban global serta }\end{array}$ \\
\hline 8. & $\begin{array}{l}\text { Setelah mengikuti pembelajaran ini mahasiswa dapat menjelaskan Hakikat } \\
\text { keragaman dan kesetaraanmanusia dan Kemajemukan dalam dinamika sosial }\end{array}$ \\
\hline 9. & $\begin{array}{l}\text { Setelah mengikuti pembelajaran ini mahasiswa dapat menjelaskan Keragaman } \\
\text { dan kesetaraan sebagai kekayaan sosial budaya Problematika keragaman dan } \\
\text { kesetaraan }\end{array}$ \\
\hline 10. & $\begin{array}{l}\text { Setelah mengikuti pembelajaran ini mahasiswa dapat menjelaskan Mengkaji } \\
\text { hakikat, fungsi, nilai, moral dan hukum dan Mengkaji keadilan, ketertiban dan }\end{array}$ \\
\hline 11. & $\begin{array}{l}\text { Setelah mengikuti pembelajaran ini mahasiswa dapat Merumuskan perwujudan } \\
\text { masyarakat bermoral dan taat hukum serta problematika nilai, moral, dan }\end{array}$ \\
\hline 12. & $\begin{array}{l}\text { Setelah mengikuti pembelajaran ini mahasiswa dapat menjelaska hakikat dan } \\
\text { makna sains, teknologi, dan seni bagi manusia serta Dampak penyalahgunaan }\end{array}$ \\
\hline 13. & $\begin{array}{l}\text { Setelah mengikuti pembelajaran ini mahasiswa dapat menjelaskan hakikat dan } \\
\text { makna lingkungan bagi manusia dan Kualitas penduduk dan lingkungan }\end{array}$ \\
\hline 14. & $\begin{array}{l}\text { Setelah mengikuti pembelajaran ini mahasiswa dapat mejelaskan problema } \\
\text { lingkungan sosial budaya dan Isu-isu penting tentang lintas budaya dan bangsa }\end{array}$ \\
\hline
\end{tabular}

\section{Langkah 3 : Menyusun Materi Perkuliahan}

Berdasarkan tujuan khusus yang telah dirumuskan maka disusun materi perkuliahan. Materi perkuliahan ini dapat menggunakan buku teks Ilmu social dasar. Materi perkuliahan selama ini disampaikan dalam bentuk diktat dan powerpoint sehingga mahasiswa mengalami kesulitan dapat memahami materi secara tuntas. Rekonstruksi materi yang dilakukan salah satunya yaitu dengan : 
1. Pembuatan modul dan diktat atau bahan ajar materi perkuliahan untuk memberi kesempatan mahasiswa untuk maju sesuai dengan kemampuannya masing-masing;

2. Memperbanyak studi kasus dalam proses pembelajaran sehingga mahasiswa dapat mengasah kemampuan analisis dalam pemecahan masalah;

3. Menambah beberapa materi pokok menjadi sub pokok

4. Dosen langsung mengimplementasikan dengan memberikan beberapa contoh ilmu social dan budaya dalam kehidupan sehari-hari

\section{Langkah 4 : Strategi Instruksional}

Berdasarkan hasil evaluasi kemudian dilakukan rekonstruksi

strategis instruksional yaitu :

1. Mulai awal semester sudah disepakati kontrak perkuliahan antara dosen dan mahasiswa;

2. Menekankan dan melatih belajar aktif kepada mahasiswa didalam ruang kuliah dalam menyelesaikan studi kasus yang telah diberikan;

3. Memberikan tugas terstruktur kepada mahasiswa yang dapat dikerjakan diluar jam kuliah dan membahas tugas tersebut didalam pertemuan berikutnya;

4. Menggunakan strategi pembelajaran bervariasi yaitu ceramah interaktif, diskusi dan tanya jawab.

\section{Langkah 5 : Strategi untuk melakukan penilaian}

Soal tes dilakukan melalui kegiatan ujian (UTS/UAS) sesuai kompetensi yang diharapkan divcapai mahasiswa yaitu :

1. Menguji kompetensi dengan kemampuan menjelaskan konsep-konsep social dan budaya dasar

2. Menguji kompetensi dengan melaukan simulasi membuat konsep-konsep social dan budaya dasar

3. Menilai progress pencapaian kompetensi secara sistematis melalui pengerjaan tugas Memasukan penilaian untuk aspek kejujuran disiplin dan sikap afektif positif lainya yang ditujukan selama proses perkuliahan berlangsung 


\section{DAFTAR PUSTAKA}

Sudiran, Florentinus. 2011. Ilmu Sosial Dasar. Laksbang : Jogyakarta

Setiadi, Elly M. dkk. 2007. Ilmu Sosial Dasar Kencana. Jakarta

Sulfemi, Wahyu Bagja. 2007. Ilmu Sosial Dasar. Bogor : STKIP Muhamadiyah Bogor

Schuon, F. 1997. Hakikat Manusia. Pustaka Pelajar. Yogakarta.

Soekanto, Soejono. 1983. Struktur Masyarakat. Rajawali. Jakarta.

Suleman, munandar. 1995. Ilmu Budaya Dasar. Eresco. Bandung

Baker, A. 1992. Ontologi: Metafisika Umum. Kanisius. Yogyakarta.

Geerzt, H. 1980. Aneka Budaya dan Komunitas di Indonsia. Yis dan FIS UI. Jakarta.

Kuntowijoyo. 1990. Metodologi Sejarah. Tiara Wacana. Yogakarta. 